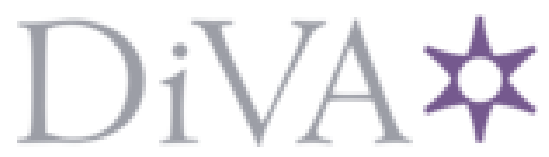

http://www.diva-portal.org

This is the published version of a paper published in Jahrbücher für Nationalökonomie und Statistik.

Citation for the original published paper (version of record):

Kokko, A., Söderlund, B., Gustavsson Tingvall, P. (2014)

Redirecting International Trade: Contracts, Conflicts, and Institutions.

Jahrbücher für Nationalökonomie und Statistik, 234(6): 688-721

Access to the published version may require subscription.

N.B. When citing this work, cite the original published paper.

Permanent link to this version:

http://urn.kb.se/resolve?urn=urn:nbn:se:sh:diva-24602 


\section{Redirecting International Trade: Contracts, Conflicts, and Institutions}

\section{Ari Kokko}

Copenhagen Business School and Ratio

Bengt Söderlund

Stockholm School of Economics and Ratio

Patrik Gustavsson Tingvall*

Ratio Institute, Sveavägen, Stockholm

JEL F23; F55; K00; P48

Exports; Offshoring; Trade; Institutions; Conflicts; Contracts.

\section{Summary}

The global financial crisis has contributed to the redirection of trade towards new markets outside the OECD area, where both demand patterns and the institutional environment differ from those in the OECD. This study provides an empirical examination of the consequences of this shift, based on Swedish firm-level trade data. Results suggest that weak institutions hamper trade and reduce the length of trade relations, especially for small firms. Trade in industries that are characterized by a high frequency of trade conflicts and where transactions require extensive relationship-specific investments are particularly difficult to redirect towards markets with weak institutions.

\section{Introduction}

Starting with a collapse in the US subprime mortgage market in 2008, the global financial crisis has left a significant mark on most of the OECD region. Several economies have been suffering from rising unemployment, fragile financial systems, and government budget and current account deficits in the trails of the crisis. Not even countries that managed to avoid severe problems in their financial sector were spared - the economic slump has been felt across the globe through large declines in international trade.

The size of the trade collapse has surprised academic observers: even accounting for the contraction in economic activity, macroeconomic models failed to predict the speed and magnitude of the reduction in global trade (Benassy-Quéré et al. 2009; Levchenko et al. 2010). During the last quarter of 2008 and the first quarter 2009, world GDP fell by approximately three percent, at the same time as world trade declined by almost 30 percent. Several explanations for this magnification effect on trade have been proposed, ranging from financial constraints, increasing importance of globally linked production chains, and rising protectionism (Baldwin 2009; Chor/Manova 2010; Evenett 2009). While all

\footnotetext{
* Financial support from Torsten Söderbergs Research Foundation is gratefully acknowledged.
} 
these factors have probably contributed to the decline, it seems that negative multiplier effects from falling demand - in the form of delayed purchases of intermediates and reductions in inventories - may still account for a major share of the trade collapse (Behrens et al. 2013).

At the same time as markets in Western Europe and North America remained sluggish after 2008, several emerging economies managed to recover quickly after the initial demand shock. The average annual GDP growth rate in the OECD area during the first four years after the crisis (2009-2012) was below one percent; in the non-OECD region, growth averaged about five percent. As a result, non-OECD markets have captured a larger share of world GDP as well as a more important role in international trade, as shown in Figure 1. The figure also shows that the shift in economic gravity towards nonOECD markets was not triggered by the crisis, but that it has instead been visible since the turn of the millennium. During the period 2000-2012, the world GDP share of nonOECD countries grew from 19 percent to 28 percent, at the same times as their share of world trade (exports plus imports) increased from 25 percent to 35 percent. Against this background, it is not surprising that the acronym BRIC was coined already in 2001 to describe some of the most important emerging market actors in this process (O'Neill 2001).

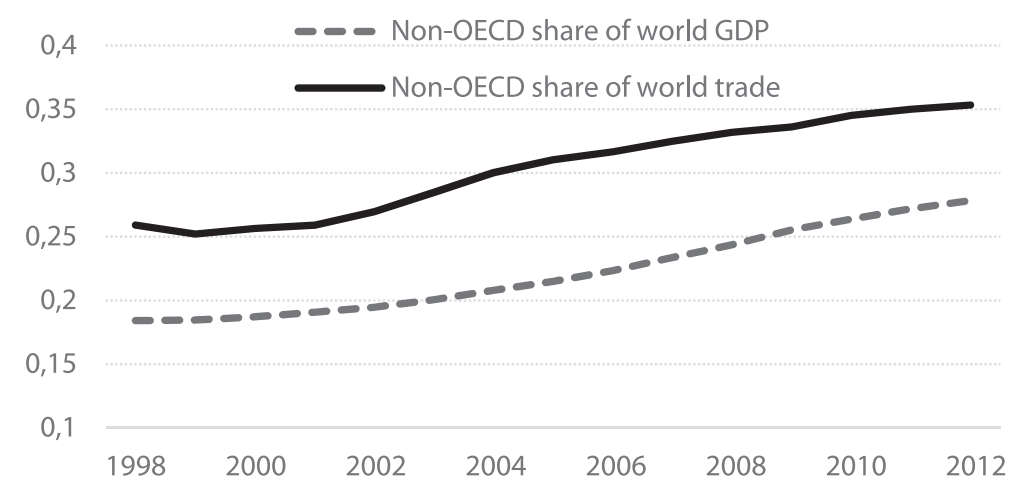

Source: World Bank Development Indicators.

Figure 1 Non-OECD Shares of World GDP and World Trade

It is not likely that the increasing importance of non-traditional markets is a temporary phenomenon - instead, most long-term projections suggest that the market shares of nonOECD economies will increase further in the future (Wilson et al. 2011; OECD 2012). This shift from traditional Westerns markets to emerging markets is a challenge for many European firms. The development of Swedish trade illustrates this. The crisis resulted in a contraction of Swedish exports by about 20 percent 2009. Trade volumes began to recover already the following year, partly as a result of an increase in the share of exports going to non-OECD markets, but total exports had barely reached their pre-crisis levels in 2012. However, the share of exports going to non-OECD destinations increased from 15-16 percent before the crisis (in 2006-2007) to over 20 percent in 2012. A similar pattern holds for most other advanced economies (CBP World Trade Monitor 2014). 
Although Swedish exporters managed to redirect some of their sales to non-OECD destinations, it is clear that the restructuring process has been a challenge. Operating in emerging markets is complex not only because demand patterns may be different than in the traditional export markets, but also because it often involves transactions in a new and unfamiliar institutional environment. The institutional barriers that have to be overcome to successfully enter these markets range from gaining knowledge about formal rules and regulations to cultural aspects of business conduct. Yet, little is known about how the large institutional differences between OECD and non-OECD markets in general may come to influence European trade patterns when the significance of non-OECD markets increases over time.

This article exploits Swedish micro data on firm-level trade to study some of the consequences for European firms of the increasing role of non-OECD countries in international trade. Since the gravity shift toward emerging markets commenced already around the turn of the millennium, we are not limited by the shortage of firm-level data for the period after the financial crisis - instead, we can exploit the entire 13-year span 1997-2009 in our empirical analysis. In particular, we focus on how two aspects that distinguish emerging markets from the traditional Western economies - their higher growth rates and weaker institutional environments - influence international trade patterns. Unlike earlier studies of trade and institutions, we include both exports and offshoring (imports of intermediate goods) in our analysis, since there are reasons to expect asymmetries between import and exports. In addition to examining the general impact of institutions and growth on trade, we focus on two types of sectoral asymmetries that may influence exports and imports in different ways. These asymmetries are related to the character of the relationship between buyers and sellers and the risk of trade conflicts.

Goods differ with respect to how important buyer-seller relations are for trade transactions - while some goods can be sold anonymously in standardized markets, personal contacts are necessary to agree about contracts for other types of goods. It is therefore more costly to trade in such relationship-specific goods, especially if institutional quality is weak it and it is uncertain whether contracts can be enforced. Hence, the relationshipspecificity of industries influences trade, often in interaction with the quality of institution in the exporting and importing economies (Nunn 2007; Araujo et al. 2012; Söderlund/Tingvall 2014). To analyze this dimension of trade, we will include a proxy for relationship-specificity from Nunn (2007) in our empirical analysis of firm-level trade.

Industries also differ with respect to the risk for trade disputes. Although the global trade policy environment is relatively transparent and liberal thanks to the WTO agreements, there are still cases where countries disagree about the interpretation of trade rules or where firms or governments engage in practices that are considered unfair by their trade partners. These cases could concern allegations of dumping, disagreements about the value of public support, customs valuation, the definition and implementation of technical or health standards, or a number of other regulatory issues associated with international trade. Since industry structure, competition, and performance differ across sectors, there are also differences in the likelihood of trade disputes - some sectors exhibit a higher conflict risk than others.

Most trade disputes are solved in bilateral negotiations between the governments and companies involved, but they still distort trade. The use of trade remedies like antidumping tariffs or other interventions by governments will interrupt trade flows. Even if disputes are eventually resolved, there are costs in terms of lost trade, time, financial resources spent on negotiations with authorities, and uncertainty about the final outcome. Uncertainty 
is likely to be higher in countries with weaker institutions, where decision-making is less transparent and decision-makers are more sensitive to pressure from various domestic interest groups. Hence, a weak institutional environment can be expected to result in a larger reduction of trade in more conflict-intensive industries. To capture this relationship in our empirical analysis, we create a new measure of conflict risk at the industry level - to parallel Nunn's (2007) measure of relationship-specificity - using data on trade disputes from the WTO Dispute Settlement Body.

Our results show that both Swedish exports and offshoring have shifted over time from the OECD region toward rapidly growing non-OECD economies that generally exhibit lower institutional quality than the traditional OECD markets. This shift is driven by differences in economic growth; trade in general and exports in particular are drawn towards high-growth economies. The redirection of trade has been moderated by the lower institutional quality in many emerging markets. In particular, weak institutions in the destination markets seem to hamper Swedish exports from industries characterized by high conflictintensity. For offshoring, the results suggest that weak partner country institutions have an especially detrimental effect in industries that exhibit high relationship-specificity. Furthermore, exports to countries that have weak institutions are characterized by relatively short-lived trade spells. This is a problem mainly for small firms that are more sensitive to uncertainty and high trade costs. Hence, the reshaping of global trade patterns has asymmetric effects on exports and offshoring, and both trade flows and the duration of trade relations are hampered by weak institutions. A continued increase in the importance of non-OECD markets will be a challenge for exporters in industries that exhibit high relationship-specificity and conflict-intensity. However, we also find signs of learning effects, suggesting that the trade-reducing impact of weak institutions may diminish over time, as exporters learn to manage the (initially) unfamiliar business environment in the destination market.

Although the study is based on Swedish data, results are generalizable to many other developed countries, since most OECD economies will face similar changes in their trade structure in the coming years. The present study contributes to the literature by highlighting some of the characteristics of developing and emerging markets and by discussing the notions of institutional learning and industry heterogeneity in the context of the current crisis. Apart from confirming the findings that industries characterized by large relationship-specific investments are more vulnerable to weak institutions (Nunn 2007) and that export spells are shorter in destination markets with weak institutions (Söderlund/Tingvall 2014), we use both export and offshoring data to show that weak institutional quality hampers export in general and exports in conflict-intensive sectors in particular, and that offshoring in sectors characterized by relationship-specific investments is held back by weak institutions. Our results also show that high growth in target economies attracts Swedish exports, but that growth in source countries has little impact on offshoring decisions.

The paper is structured as follows. Section 2 discusses theoretical findings on the relations between institutions, contracts, and trade conflicts. Section 3 presents the empirical approach for the study, Section 4 focuses on data sources and descriptive statistics, and Section 5 presents and discusses the results from the empirical analysis. Section 6 summarizes and provides some policy conclusions. 


\section{Theory and literature: institutions, contracts, and conflicts}

Emerging markets differ in many respects from the traditional export destinations of Western European firms. They have lower per capita income levels than the OECD countries, they are typically located far away from Western Europe, both in terms of geographic and cultural distance, and economic institutions are less developed (or at least different) than those in Europe. All of these differences will pose significant challenges for European exporters as the importance of emerging markets as export destinations grows.

Some of these challenges have been discussed in detail in the international trade literature. Differences in per capita incomes do not only reflect differences in labor costs and comparative advantage, but also differences in consumer preferences. Linder (1961) provided an early analysis of how similarity in domestic demand - which is expected to be correlated with similarity in per capita incomes - influences trade patterns. Later contributions have noted that countries at different income levels will perhaps not demand different product categories, but rather different product varieties, with quality and price as important variables (Bernasconi 2009; Hallak 2010). This suggests an increasing need to adapt products to local market conditions.

Geographic distance remains an important determinant of bilateral trade, despite the reductions in transport costs achieved in the past decades (Disdier/Head 2008). The distance paradox suggests that trade with far-away markets is not only burdened by high transport costs, but that there may also be other types of transaction costs that increase with distance. In the international business literature, it has been common to point to "cultural distance" as a determinant of transaction costs (Kokko/Tingvall 2014). Although cultural distance is discussed also in the international trade literature, many trade researchers have instead chosen to emphasize the role of institutions. In fact, recent research has shown that the impact of institutions on international trade can be even greater than the impact of tariffs (Belloc 2006; Anderson/Marcoullier 2002; MárquezRamos et al. 2012; Levchenko 2007). Given our focus on institutions, it is appropriate to take a closer look at how economic theory expects institutions to influence international trade.

\section{Institutions and international trade}

Stable rules and well-functioning institutions are important determinants of long-term trade relations. ${ }^{1}$ The theoretical links between trade and institutions are highlighted in transaction cost economics (Williamson 1985, 1996) and the property rights view introduced by Grossman and Hart (1986) and Hart and Moore (1990). Both approaches address incomplete contracts and the make-or-buy decision, with the property rights view focusing on ownership as a determinant of trade, and the transaction cost perspective adopting a broader view based on contract execution. ${ }^{2}$

Contractual issues affect both parties in any trade agreement. As specified in the standard hold-up problem, the seller often needs to make contract-specific investments. However, a decision by the prospective seller to invest will shift bargaining power to the prospective buyer. Once the seller has made the necessary investment, the buyer may be tempted to

\footnotetext{
1 There is no universally accepted definition of institutions. We follow North (1991), who states that, "Institutions are the humanly devised constraints that structure political, economic and social interaction".

2 For a more detailed discussion, see Williamson (2000).
} 
request a renegotiation of the transaction terms, to the detriment of the seller. If this renegotiation fails, the buyer may be able to find an alternative supplier at little extra cost, whereas the seller risks losing all or part of the sunk investment cost. One way to minimize risks related to opportunistic behavior is to invest in complex contracts that carefully define the rights and obligations of all parties involved in the transaction. The problem is that truly complete contracts can neither be formulated nor enforced, which results in some degree of underinvestment. This is a particularly severe challenge for international trade, where enforcement possibilities are weaker because the parties are located in different countries with different jurisdictions (Ornelas/Turner 2008).

Institutions have an impact on international trade because they influence the costs for administration and contracting and the risk of opportunistic behavior. Efficient institutions facilitate trade by offering stable rules that reduce uncertainty, secure property rights, enhance law enforcement, and facilitate interpersonal exchanges that allow more complex and efficient ways of organizing production and trade (North 1991; Williamson 2000; Massini et al. 2010). Institutions can also affect the costs of monitoring and control. Since contract costs can determine whether a cross-border relationship will be established, effective institutions are central to facilitating trade.

In line with these theoretical predictions, empirical evidence suggests that weak institutions raise the cost of doing business, hamper investment, and influence trade patterns. For instance, Anderson and Marcouiller (2002) and Ranjan and Lee (2007) use gravity models to assess how institutions affect bilateral trade flows, and find significant effects. Méon and Sekkat (2006) show that the level of corruption, rule of law, government effectiveness, and political violence all impact exports of manufactured goods. Awokuse and Yin (2010) show that strengthened intellectual property rights in China have had a particularly strong impact on imports of knowledge-intensive products. Focusing on border effects, Turrini and van Ypersele (2010) conclude that differences in legal systems reduce trade flows.

Apart from reducing trade volumes, weak institutions may also affect the duration and the dynamics of trade (Aeberhardt et al. 2011; Araujo et al. 2012; Söderlund/Tingvall 2014). As shown by Araujo et al. (2012), trade with countries with weak institutions is characterized by short-lived trade flows and small initial volumes. Subsequently, trade flows may increase as exporters become more familiar with their contractual partner and learn about the institutional environment in the target economy. These contributions constitute an important link between international trade and international business - in international business, it has long been hypothesized that internationalization is a gradual process, where firms enter distant markets cautiously and raise their level of commitment only after learning about their partners and the local market environment (Johanson/Wiedersheim-Paul 1975; Johanson/Vahlne 1977). We add to this literature by, among other things, complementing it with the role of trade conflicts and income growth.

\section{Relationship-specificity and conflict-intensity}

Institutional quality in the target economy is likely to have a composition effect on trade. When sensitive information is involved, the contracting process easily becomes complex, time consuming, and expensive (Antràs 2003). Trade in sectors with these characteristics will be intensive in seller-buyer interactions and may therefore be especially sensitive to weak institutions. With this as a point of departure, and drawing on Rausch (1999), Nunn 
(2007) developed an index that measures the industry-specific degree of relationshipspecificity (RS). This index signals how frequent personal interactions between the buyer and the seller are for contract completion (for different industries or types of goods). A main finding in Nunn (2007) is that countries with well developed legal institutions have a comparative advantage in trade in RS-intensive goods.

Since Nunn (2007), several papers have studied how relationship-specific interactions influence various commercial decisions. For instance; Altomonte and Békés (2010) analyze trade and productivity, Casaburi and Gattai (2009) focus on intangible assets, Ferguson and Formai (2013) examine trade, firm choice and contractual institutions, Bartel et al. (2005) study outsourcing and relationship-specific interactions, Kukenova and Strieborny (2009) look at finance and relationship-specific investments, and Söderlund and Tingvall (2014) investigate the impact of institutions on trade dynamics. The general pattern emerging from these studies is that relationship-specificity matters, but that the effects on trade flows depend on the institutional environment in the partner countries. Trade in industries with a high RS-index is particularly likely to suffer when institutions are weak.

Aside from buyer-seller interactions, trade relations may also be influenced by public policy interventions. Although the general policy environment for world trade is relatively predictable, since most countries are members of WTO and have pledged to follow WTO principles and tariff schedules, there is some degree of uncertainty related to how various trade rules should be interpreted. Trade disputes are not unusual. Disagreements and trade conflicts can focus on administrative procedures connected to technical standards, import licenses, and customs valuation, as well as the use of trade remedies like anti-dumping tariffs and countervailing duties.

Trade conflicts can severely hamper trade and are more likely to occur in some industries than in others, either because of their strategic value to either of the trade partners, or because of the influence of protectionist interest groups in the importing economy. Since trade in conflict-intensive sectors is associated with uncertainty and risk, and a key feature of institutions is to reduce uncertainty and risk, the role of institutions may be particularly important in these sectors.

The framework for anti-dumping can be used to illustrate some of the issues involved in trade conflicts. Anti-dumping investigations are normally initiated by national governments at the request of domestic firms or industry associations asserting that foreign exporters are causing injury by selling goods at unnaturally low prices. The aim of the investigation is to determine whether this is the case - both domestic and foreign firms are expected to have an opportunity to present their views during this process. The introduction of specific anti-dumping tariffs is then determined by the national trade authorities. WTO defines the rules for when anti-dumping remedies can be used, and provides a dispute resolution mechanism where foreign exporters can challenge the decisions of the national authorities, but is otherwise not involved in anti-dumping cases.

Member countries reported a total of 4.230 anti-dumping investigations to the WTO between 1995 and 2012. Both developed and emerging markets appear among the reporters - India reported the most investigations, followed by the US and EU. Argentina, Brazil, Australia, South Africa, China, Canada, and Turkey completed the top-10 list. The anti-dumping investigations were not evenly distributed across industries, but instead concentrated to specific sectors, often with fierce price competition, substantial political influence, and/or strategic importance. According to the WTO, chemical products, plas- 
tics, metal products, textiles, and machinery accounted for the majority of the investigations. ${ }^{3}$ The incidence of anti-dumping investigations at the sectoral level provides one indication of how exposed different sectors are to trade conflicts.

The ratio of tariffs to investigations varies between countries. In the US, EU, Australia, and Canada, two-thirds of the investigations led to the introduction of tariffs, while one-third of cases were judged not to involve dumping or injury to local industry. In India, China, Argentina, and Turkey, $75-90 \%$ of investigations resulted in tariffs. This may reflect the weaker institutional environment in some of the emerging markets - the likelihood that foreign exporters will be able to influence the outcome is lower when legal and political institutions are weaker.

A drawback with anti-dumping investigations is that they only capture one type of trade conflicts. A more general indicator of conflict intensity can be derived from the WTO's Dispute Settlement Body. ${ }^{4}$ Disagreements regarding trade are sometimes so severe that one or several of the parties file a complaint at WTO's Dispute Settlement Body. By November 2013, 99 disputes concerning anti-dumping tariffs had been filed at the WTO. This is a small share of the anti-dumping tariffs imposed by the national authorities of WTO members, but they represent $28 \%$ of the cases related to specific products in the WTO dispute settlement system. Countervailing duties account for an equal share of cases, with technical standards, import licensing, and customs valuation covering most of the remaining goods-related disputes. ${ }^{5}$ We extract the cross industry distribution of 479 disputes taken to the WTO dispute settlement body and construct a conflict-intensity (CI) index corresponding to Nunn's (2007) RS-index. ${ }^{6}$

The CI-index is not only interesting per se, but in particular in interaction with measures of institutional quality. A well-functioning institutional framework provides stable and clear rules for trade and reduces the risk that political objectives or pressure from domestic interest groups will disturb trade relationships. These advantages are especially important in industries where trade conflicts are frequent. Hence, we expect the interaction between conflict intensity and institutional quality to be positively associated with trade. To be precise, the hypothesis is that the impact of weak institutions is magnified in conflict-intensive industries; this parallels the interaction between relationship-specificity and institutional quality suggested by Nunn (2007).

Summarizing, theory suggest that better contracting institutions favor trade and that the impact of weak institutions is stronger in industries requiring close interactions between sellers and buyers and in industries where conflicts are more frequent. To empirically explore how these theoretical findings help to predict the consequences of a shift in global trade towards emerging markets and developing economies, we will exploit the gravity model of trade, which is a commonly used tool in empirical trade analysis. The next section turns to a discussion of that model.

3 All the data on disputes are from http://www.wto.org/english/tratop_e/dispu_e/dispu_e.htm, retrieved in October 2013.

4 See Horn et al. (2011) for descriptive statistics on disputes taken to the WTO Dispute Settlement Body.

5 The remainder of the 469 disputes in the WTO system refers to services or various general issues that are not limited to any specific product cathegory.

6 Due to data issues and to conform to the RS-index, the cathegory analysis is limited to the manufacturing sector. Out of 479 WTO trade disputes, the manufacturing sector accounts for 325 disputes. 


\section{Empirical approach}

\subsection{Choosing estimator}

Our empirical analysis is based on the gravity model, which is one of the most commonly used tools in empirical trade analysis. The theoretical support for the gravity model was weak when it was originally introduced in the early 1960s (Tinbergen 1962), but a series of theoretical contributions since the late 1970s have shown that it is consistent with several of the most common trade theories (Bergstrand 1990). However, Anderson and van Wincoop (2003) showed that the traditional specification of the gravity model suffers from an omitted variable bias by overlooking the effects of relative prices on trade patterns. They argue that the inclusion of a multilateral trade resistance term, in the form of importer and exporter fixed effects, will be sufficient to yield consistent parameter estimates. In our empirical analysis, we estimate a one-sided gravity model where country dummies are included in all estimations to overcome the omitted variables bias. We also perform robustness tests by varying the set of fixed effects included in the estimations. ${ }^{7}$. The literature on gravity modeling does not provide any decisive guidance on which estimator to prefer in applied work. Different estimators have their own sets of advantages and disadvantages. For example, the OLS estimator with country fixed effects is likely to avoid the multilateral trade resistance trap and it is probably the most commonly applied estimator in gravity model estimations. However, the log-linear OLS estimator does not naturally allow for the inclusion of zero valued trade flows. An alternative to OLS that provides a natural way of including zero value observations is the Heckman model. The Heckman model, in turn, is sensitive to the use of multiple dummies and vulnerable to heteroscedasticity. Lately, the OLS and Heckman estimators have been challenged by count data models from the Poisson family as well as negative binomial estimators. The advantage of these estimators it that they naturally allow for the inclusion of zero values, they are consistent in the presence of fixed effects, and they are robust against heteroscedasticity. Moreover, these estimators do not rely on any specific exclusion restriction.

With this as a background, it is not surprising that the zero inflated beta distribution model (ZOIB) has become increasingly popular in the estimation of gravity models. This model allows zero valued trade flows to be treated as if generated through a different process than non-zero valued observations. More specifically, the zero inflation part of the ZOIB model, the zero inflation part of this model deals with the likelihood of observing zero valued trade. The estimated coefficients for the inflation step in the model are expected to be of the opposite sign as those of a logit model, which predicts the likelihood of entering a positive trade flow (Ferrari/Cribari-Neto 2004; Paolino 2001; Smithson/Verkuilen 2006). It should also be noted that the ZOIB model focuses on ratios, which means that we transform our dependent variables to represent export and offshoring ratios (as shares of total sales) rather than total trade flows. Hence, the estimated coefficients from the ZOIB model are not elasticities but rather semi-elasticitis.

An alternative to the ZOIB model is the zero inflated negative binomial model (ZINB). The ZINB model allows the inclusion of total trade flows even when the dependent variable contains excessive zeros (overdispersion). Furthermore, like the ZOIB model, the ZINB model allows the excess zeros to be generated by a separate process than the non-zero valued observations. In our estimations below, Vuong tests of overdispersion favor the

\footnotetext{
7 Other approaches include a two-step method that models the multilateral trade resistance term as a function of observables (Anderson/van Wincoop 2003; Feenstra 2004)
} 
ZINB to the standard NB model, which is more suitable in data sets with a smaller share of zero valued observations. The ZIP test shows that the variance is greater than the variance of the dependent variables suggesting the ZINB model in favor of the zero inflated Poisson model.

To manage these estimator problems, we present models using both the ZOIB and the ZINB estimator. The reason is that we want to ensure that results are not dependent on the use of a specific estimator. ${ }^{8}$ Moreover, to avoid extremely large datasets, we follow Koenig et al. (2010) and drop permanently non-trading firms from the estimations. It may also be noted that the 2008-2009 crisis mainly affected the intensive margin of trade for Swedish firms (confirming the pattern for Belgium found by Behrens et al. 2013). Hence, the inference is concentrated to firms participating in international exchange, or firmcountry pairs that record at least one positive value during the period of observation. For the export estimations, this leaves approximately 1,000,000 observations out of which about 500,000 consist of positive trade flows; for offshoring the corresponding numbers are 400,000 observations and 200,000 positive trade flows. For the extensive margin, i.e. the selection into positive firm-country trade, we use a dummy variable which takes the value 1 if the firm is trading at time $(t)$ with country $(j)$ and 0 otherwise. For the intensive margin, we use the volume of trade (exports or offshoring) at the firm-country level, except for the ZOIB model where we use the export and offshoring ratios. Because of the hierarchical structure of data, all estimations are performed using robust standard errors clustered by country-year.

\subsection{Variables and model specification}

Institutions are at the center of our analysis and we have therefore used several different data sources to construct robust proxies for institutional quality. These proxies cover 12 measures of institutional quality related to various aspects of rule of law and business institutions. The underlying indices are drawn from sources such as the World Bank, the Heritage Foundation and the Fraser Institute (for details, see the data section). We normalize all the underlying indices to range between 0 and 10, with higher numbers indicating "better" institution. Thereafter, we calculate the institutional quality as the average score for each country and year. This provides a broad measure of overall institutional quality $\left(\right.$ Inst $\left._{c t}\right)$.

Our industry specific measure of contract intensity is captured using Nunn's (2007) relationship-specificity measure $\left(\mathrm{RS}_{j}\right)$. To measure the conflict intensity in an industry $\left(\mathrm{CI}_{j}\right)$ we use data on trade conflicts taken from the WTO dispute settlement system (described above). The applied conflict intensity index is based on 325 disputes in the manufacturing sector reported to the WTO dispute settlement body between 1995 and 2010 , involving 57 industries. A trade conflict is recorded when a member country raises a complaint within the WTO dispute settlement system. Following Horn et al. (2011), we define conflicts at the bilateral level, which means that when two countries file a complaint against a third member, it is counted as two bilateral complaints. However, only 9 out of the 469 disputes registered by October 2013 had more than one complainant. It is common that countries join complaints as third parties, but these are not counted as separate disputes. Moreover, the calculation of the conflict-intensity index only includes

\footnotetext{
8 We have also estimated all models presented in Table 2 using OLS and Heckman models with similar results, available upon request.
} 
conflicts that are clearly focused on specific goods categories - complaints regarding general administrative practices and services are dropped from the calculations. Although most disputes cover one or two 3-digit industries, there are some cases where up to four industries are involved at the same time. Examples of goods that rank high in conflict intensity include pharmaceutical products, iron and steel and motor vehicles whereas there are no conflicts recorded in the WTO dispute settlement body in goods such as jewelry, toys, sports equipment and wood products. We limit the analysis to the manufacturing sector, partly because Nunn's (2007) RS-index is only defined for that sector. To compensate for size differences across industries, we weight the number of disputes in each industry with the relative size of that industry.

In the analysis, we put particular stress on the interaction effects between institutional quality and contract intensity $\left(R S_{j} \cdot\right.$ Inst $\left._{c t}\right)$, as in Nunn 2007 , and the interaction between institutional quality and industry conflict intensity $\left(C J_{j} \cdot I n s t_{c t}\right)$. This means that we analyze heterogeneous effects of institutional quality in sectors with different degrees of conflict risk and relationship-specificity. A positive estimated coefficient for the interaction terms $\left(R S_{j} \cdot I n s t_{c t}\right)$ and $\left(C J_{j} \cdot I_{n s t}\right)$ implies that contract and conflict intensive industries are particularly sensitive to institutional quality it target economies. With this as a background, a representative export model for the zero inflation step in the ZINB model takes the following form: ${ }^{9}$

$$
P\left(D_{i j c t}^{x}=1 \mid \text { observables }\right)=\Phi\left(\sum_{k} \delta_{k} F_{k i j t}+\sum_{l} \delta_{l} C_{l c t}+\sum_{c} \beta_{c} D_{c}+\gamma_{t}+\varepsilon_{i j t}\right)
$$

where $D_{i j c t}^{x}=1$ is a dichotomous dependent variable that takes the value 1 if firm $(i)$ is active in industry (j)'s exports to country $(c)$, and $F_{k i j t}$ is a set of $\mathrm{K}$ explanatory firm-level variables, $C_{l j t}$ is a set of $\mathrm{L}$ explanatory country level variables, $D_{c}$ are country dummies, $\gamma_{t}$ are period dummies, $\varepsilon$ is the error term $\delta_{k}, \delta_{l}$ and $\beta_{c}$ are estimated coefficients. The offshoring estimation is defined in a similar way, with the dependent variable taking the value 1 if firm ( $i$ ) is active in industry ( $j$ )'s source intermediates from country $(c)$. For the inflation equations, we use the variables specified in Eq. 2 below, to which we add data on the share of workers with tertiary education. ${ }^{10}$

The intensive margin of trade, defined as the volume of trade (exports or offshoring) in the ZINB model and the intensity of trade (exports/sales, offshoring/sales) in the ZOIB model, is estimated as:

$$
\begin{aligned}
(\text { Trade })_{i j c t}=\alpha & +\beta_{1} \ln (Y)_{c t}+\beta_{2} \ln (L)_{i j t-1}+\beta_{3} \ln (\text { TFP })_{i j t-1}+\beta_{4} \ln (\text { Dist })_{c}+\beta_{5}(\text { Inst. })_{c t} \\
& +\beta_{6}(R S)_{j}+\beta_{7}(C I)_{j}+\beta_{8}\left[(\text { Inst } .)_{c t} \cdot(R S)_{j}\right]+\beta_{9}\left[(\text { Inst. })_{c t} \cdot(C I)_{j}\right] \\
& +\beta_{10}(\text { Tariff })_{j c t}+\beta_{11}(\text { Foreign })_{i j t}+\sum_{c} \beta_{c} D_{c}+\gamma_{t}+\varepsilon_{i j t}
\end{aligned}
$$

where Trade $i j c t$ is exports(offshoring) by firm $i$, active in industry $j$, to(from) country $c, Y$ is GDP of the target economy, firm-level gravity is captured by the number of employees,

\footnotetext{
${ }^{9}$ Note that the inflation step in the ZOIB model focuses on the likelihood of observing zero valued trade flows.

${ }^{10}$ Bernard and Jensen (2004) argue that in addition to skill intensity, characteristics such as firm-size, productivity, ownership and product mix impacts the probability of becoming an exporter. See also Roberts and Tybout (1997).
} 
L, TFP is firm level productivity captured by the Levinshon and Petrin (2003) productivity index estimated at the two digit industry level, Dist is the geographical distance between countries, Inst is a measure of the institutional quality of the target economy, $C I$ is the industry specific measure of conflict intensity, $R S$ is the measure of relationship-specificity from Nunn (2007), Tariff is the trade-weighted tariff, Foreign is a firm level dummy variable indicating foreign ownership, $D_{c}$ are country dummies, $\gamma_{t}$ are period dummies and $\varepsilon$ is the error term. Due to potential endogeniety and impact lags, firm size and firm level productivity are lagged one year. ${ }^{11}$

\section{Data and descriptive statistics}

The firm-level data originate from register-based data sets from Statistics Sweden covering the whole economy spanning the period 1997-2009. The Business Statistics data base contains detailed firm-level information on firms' inputs and output. Examples of the variables included are value added, capital stock, investments, number of employees, total wages, the composition of the labor force with respect to educational level and demographics, ownership status, profits, sales, and industry affiliation. ${ }^{12}$

Data on firms' exports and imports of goods originate from the Swedish Foreign Trade Statistics, which provide information on trade at the product level tagged by country of origin (offshoring) and destination country (exports). For non-EU trade, all trade transactions are registered. Data on trade with EU countries are available for all firms with yearly imports or exports exceeding 1.5 million SEK (approx. 150,000 EUR). According to information from Statistics Sweden, the data cover 92 percent of the total trade with the EU. Material offshoring is identified by aggregating imports of intermediate inputs according to the MIG code classification that groups products with respect to the intended use (intermediate input, investment, final consumption etc.). ${ }^{13}$ We measure offshoring as imports of intermediate inputs - this measure of offshoring is likely to be more precise than most other measures used in the literature (Hijzen 2005). To make the sample of firms consistent across time and to reduce the impact of non-registered transactions within the EU, we restrict our analysis to firms in the manufacturing sector with at least 30 employees.

GDP and population data is collected from the World Bank database. GDP data are in constant 2000 USD prices. Data on distances are based on the CEPII population weighted measure. ${ }^{14}$ Tariff data are obtained from the UNCTAD/TRAINS database.

Institutional data originate from The World Bank Governance Indicators (WGI) developed by Kaufman et al. (1999) (rule of law), the Fraser Institute (legal structure and property rights, freedom to trade, regulation of credit and business, access to sound money) and the Heritage Foundation (property rights, business freedom, economic freedom index, financial freedom, fiscal freedom, monetary freedom, investment freedom, freedom to trade). Due to different time spans for variables in the dataset, and in particular the lack of firm-specific trade data for the last few years, we limit the analysis to the period 1997-2009. We normalize all institutional indices to range between 0 and 10, with higher numbers indicating "better" institutions.

11 Tariffs and country characteristics are viewed as exogenous to the individual firm.

12 All variables are deflated to 1997 constant prices using the consumer price index.

${ }^{13} \mathrm{MIG}$ is a European Community classification of products: Major Industrial Groupings (NACE rev1 aggregates).

${ }^{14}$ More information on CEPII's distance measure is found in Mayer and Zignago (2006). 


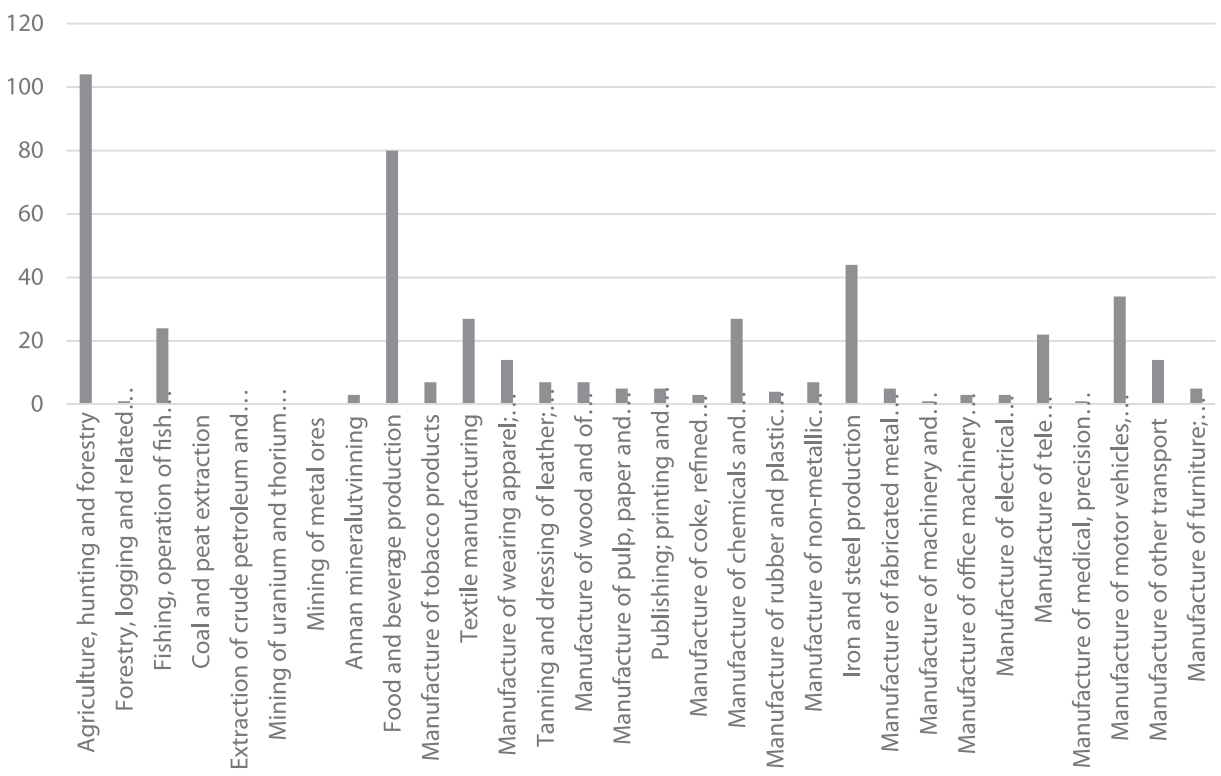

Figure 2 Number of trade conflicts reported to the WTO dispute settlement body, 1995-2010, per industry group

Data for the relationship-specificity index $R S_{j}$ is taken from Nunn (2007) (available at http://scholar.harvard.edu/nunn/pages/data-0). The RS-index has a theoretical range of $0-1$.

Data for the conflict-intensity index $C I_{j}$ is extracted from the on WTO dispute statistics (http://www.wto.org/english/tratop_e/dispu_e/dispu_e.htm). The goods targeted by the disputes are identified by their HS-code at various levels of disaggregation. Each dispute also has a descriptive title that spells out what types of goods are involved. We have translated the HS-codes to the relevant Swedish industry codes (SNI92) at the 3-digit level. To compensate for size differences across industries, we weight the number of disputes in each industry with the relative size of that industry. The weighted CI-index is skewed to the with a mean of 0.11 and a range from 0 to 3 . Figure 2 provides an overview of the number of conflicts per industry category.

\subsection{Descriptive statistics}

Before the econometric analysis, it is useful to highlight some descriptive statistics on the trade patterns of Swedish firms. It was noted in the introduction that the global financial crisis resulted in an increase in the non-OECD share of Swedish exports from 16 percent in 2006 to over 20 percent in 2012. This was a notable increase, but the trend towards a growing non-OECD share had been evident already before the crisis: the nonOECD share had grown steadily from about 11 percent in 1999 to 16 percent in 2006. Table 1 presents data for the sample of firms included in our regression estimations and shows how the non-OECD shares of exports and offshoring developed during the period 
1997-2009. A first observation is that the OECD region still accounted for the dominant share of Swedish trade in 2009, despite the increases in non-OECD shares since the turn of the millennium. The concentration of offshoring to OECD countries (which accounted for 83 percent of offshoring in 2009) may be somewhat surprising, since the academic debate on offshoring has had a focus on North/South trade. However, Grossman and Rossi-Hansberg (2012) have recently provided theoretical arguments to explain the large volume of North/North offshoring. The relative resilience of the OECD as a destination for offshoring is probably also explained by the strong bargaining position of buyers at the time. Given the large reduction in demand brought about by the crisis, Swedish importers were in a good position to negotiate favorable agreements with OECD suppliers. Moreover, the large share of intermediates sourced from the OECD probably indicates that offshoring to a large extent is about finding highly specialized suppliers.

A second observation is that the smallest firms have not been very successful in redirecting their exports toward non-OECD markets. The upper part of Table 1 shows the changes in non-OECD shares of trade for different size categories of firms between 1997 and 2009. Firms in the "small" category have 30-50 employees, medium-sized firms have 51-500 employees, and large firms have more than 500 employees. For exports, the pattern is distinct: larger firms have a relatively large share of their sales directed to non-OECD markets. For offshoring, there are only small differences between size categories.

Table 1 Trade patterns and industry characteristics in Swedish trade

\begin{tabular}{|c|c|c|c|c|c|c|c|}
\hline \multicolumn{8}{|c|}{ Non-OECD shares of Swedish Exports and Offshoring 1997-2008 } \\
\hline \multicolumn{4}{|c|}{ Export } & \multicolumn{3}{|c|}{ Offshoring } & \multirow[b]{2}{*}{2009} \\
\hline$\%$ & 1997 & 2006 & 2009 & & 1997 & 2006 & \\
\hline Small & 12 & 18 & 21 & Small & 6 & 14 & 17 \\
\hline Medium & 16 & 21 & 23 & Medium & 7 & 14 & 17 \\
\hline \multirow[t]{2}{*}{ Large } & 23 & 28 & 33 & Large & 7 & 16 & 17 \\
\hline & \multicolumn{2}{|c|}{ Exports } & & & \multicolumn{3}{|c|}{ Offshoring } \\
\hline (year 2009) & All & OECD & non-OECD & & All & OECD & non-OECD \\
\hline $\begin{array}{l}\text { Avg. Cl-index } \\
\text { Avg. RS-index } \\
\text { Avg. Inst }\end{array}$ & $\begin{array}{l}3,17 \\
0,52 \\
7,23\end{array}$ & $\begin{array}{l}3,33 \\
0,52 \\
7,77\end{array}$ & $\begin{array}{l}2,98 \\
0,52 \\
6,56\end{array}$ & & $\begin{array}{l}3,83 \\
0,52 \\
7,58\end{array}$ & $\begin{array}{c}3,9 \\
0,51 \\
7,85\end{array}$ & $\begin{array}{l}3,61 \\
0,54 \\
6,68\end{array}$ \\
\hline \multirow{2}{*}{ Avg. Inst } & \multicolumn{4}{|c|}{ Exports } & & \multicolumn{2}{|c|}{ Offshoring } \\
\hline & & & OECD Non & & & OECD & Non-OECD \\
\hline \multicolumn{2}{|c|}{ Volatility (stdv/mean) } & & 10.05 & & & 10.59 & 14.62 \\
\hline
\end{tabular}

Table 1 also illustrates some of the differences between OECD and non-OECD markets with respect to institutions and industry characteristics. The middle part of the table shows the trade weighted values of institutional quality (Inst), relationship-specificity (RS-index) and conflict intensity (CI-index) for OECD and non-OECD economies. Institutional quality is higher in OECD countries, and the average value of the CI-index is also somewhat higher for the trade flows with the OECD region. The lower CI-index in the non-OECD countries could be a response to the higher risk connected to weak institutions in this region. The difference in the RS-index between trade with OECD and non-OECD markets is marginal, which is perhaps somewhat surprising, given the theoretical prediction that 
weak institutional quality is likely to discourage trade in relationship-intensive products. This suggests that the mix of contract intensive goods and goods that do not require much seller-buyer interactions is rather similar between OECD and non-OECD countries. The average CI-index is higher for offshoring than for exports, which is reasonable given that trade conflicts typically concern access to destination markets: Swedish firms should have a good understanding of European trade policy, and therefore little reason to worry about policy conflicts that might disturb import transactions. There is no difference between the average RS-index for exports and offshoring.

The bottom part of Table 1 presents a measure of the volatility of trade flows, calculated as the ratio of the standard deviation of trade volumes to the average trade volume. The pattern is clear: trade relations with non-OECD countries are more volatile than relations with other OECD countries. As we will see later (in Figure 4), the trade flows with non-OECD countries are also relatively short-lived compared to trade flows with OECD countries.

\section{Analysis}

\subsection{Basic results}

Behrens at al. (2013) showed that the collapse of international trade during the financial crisis was concentrated to the intensive margin of trade (the volume and value of trade) while the extensive margin (the number of traded goods and trading firms) was remarkably stable throughout the crisis. A similar pattern characterized the 1997 financial crisis in Asia. This leads us to focus our analysis on the intensive margin, although estimations of the extensive margin are included for completeness.

With the descriptive results as a backdrop, Table 2 looks at the determinants of Swedish exports and offshoring, with the interaction between institutional quality and the two indices measuring relationship-specificity and conflict-intensity $\left(R S_{j} \cdot I n s t_{c t}\right)$ and $\left(C I_{j}\right.$. Inst $t_{c t}$ ) as our main variables of interest. To provide an indication of the robustness the results, Table 2 presents regressions using both the ZOIB and ZINB estimators (subsequent estimations concentrate on the ZOIB model). Columns 1-2 and 5-6 focus on the intensive margin of trade for offshoring and exports, respectively. Columns 3-4 and 7-8 examine the process for zero valued trade (zoib zero inflate) and the extensive margin, the selection into trade (zinb inflate). It should be noted that the zero inflation step of the ZOIB model reflects the odds for observing zero valued observations, while the inflation step in the ZINB model is a logit model that captures the odds of a non-zero observation. We therefore expect the two inflation models to show opposite signs.

Looking first at the control variables, it can be seen that firm-level productivity has the expected positive impact on the intensive margin of trade. This holds for both total trade flows and trade as a proportion of total sales. Most estimations on the extensive margins of trade also support the hypothesis that more productive firms are selected into trade. The standard gravity variables, firm size and GDP, have the expected positive Sign and are statistically significant for the absolute volume of exports and offshoring, but they have less influence on exports and offshoring as a share of total sales. Foreign owned firms are more open to trade than other firms, suggesting that their connections with affiliated firms outside Sweden facilitate internationalization. The impact of tariffs is mixed, with mostly insignificant estimates. The insignificance of tariffs may be due to fact that the great majority of Swedish trade takes place within the scope of various free trade 
arrangements. As noted earlier, it is also likely that various informal barriers make up a greater obstacle to trade than do formal tariffs (Söderlund/Tingvall 2014). The results for exports suggest that skill-intensive firms are more likely to become exporters, while the results for offshoring are inconclusive.

Turning to the variables of interest, the estimations in Table 2 show that institutional quality has a positive direct impact on the intensive margins of exports and offshoring. That is, both the intensity of trade and the absolute quantities of exports and offshoring are positively related to institutional quality in the target economies. The direct impact of the RS-index on offshoring is mostly negative, but the results for exports are mixed. Looking at the interaction between institutional quality and relationship-specificity, the estimations suggest that strong institutions are particularly important for facilitating offshoring in RS-intensive industries. The interplay between institutions and seller-buyer interactions is less clear for exports. Put differently, a high RS-index value reduces offshoring, but good institutions moderate this negative effect. Considering that offshoring implies a relatively deep engagement with the contracting partner, this is an expected result. Offshoring of complex and contract-intensive goods can involve the transfer of management control, decision making, and firm-specific knowledge, and it is therefore plausible to assume that institutional quality can be an important determinant of uncertainty and contracting costs. For standardized products, institutional quality is less likely to be an issue.

For the trade conflict variable CI, we mostly find positive and significant coefficient estimates, which reflect the fact much of world trade takes place in industries where conflicts are relatively common. The interaction term $\left(C I_{j} \cdot I n s t_{c t}\right)$ is positive and significant in the export estimations, indicating that strong institutions enhance exports in conflict intensive industries, but the interaction effect between institutions and conflict risk in offshoring is less systematic. This result suggest that well functioning institutions in target economies reduce the uncertainty involved in foreign market entry and that this is especially important in industries where trade conflicts are frequent. It should be noted that the simple correlation between the RS-index and the CI-index is only 0.08 , which means that they can be used simultaneous in the same model - they seem to absorb separate and distinct features of industries. Hence, trade conflicts are not particularly concentrated to industries where intensive contacts between buyers and sellers are required.

The asymmetry captured by the interaction terms reveals the impact of institutions at the average values of the RS and CI-indices. To visualize how the effect of institutional quality varies across different values of the indices, we have therefore calculated the marginal impact of institutional quality on trade for the full span of observed values of the RS and CI-indices. More precisely, on the basis of the ZOIB estimations (columns 1 and 5 ) in Table 2, the left-hand panels of Figure 3 show the estimated marginal impact of institutional quality for all observed values of the RS-index, holding the CI-index and the institutional quality index fixed at their mean values. ${ }^{15}$

The right-hand panels show the marginal impact of institutional quality across all observed values of the CI-index, calculated in the same way. As indicated by the interac-

\footnotetext{
${ }^{15}$ Formally, using equation 1 , in a linear model, the marginal impact if institutions is calculated as $\frac{d(\text { trade })}{d \text { (inst })}=\beta_{\text {inst }}+\beta_{8}(R S)_{j}+\beta_{9}(C I)_{j}$, where the RS and $\mathrm{CI}$ index has been centered at their mean values. To show how the marginal effect varies with respect to different values of the RS- and CI-index we allow them to vary over the observed range. The standard error of the marginal effect is, $s t d v=\sqrt{V\left(\beta_{\text {inst }}\right)}+(R S)^{2} V\left(\beta_{8}\right)+(C I)^{2} V\left(\beta_{9}\right)+2 \operatorname{cov}\left(\beta_{\text {inst }}, \beta_{8}\right)+2 \operatorname{cov}\left(\beta_{\text {inst }}, \beta_{9}\right)$.
} 


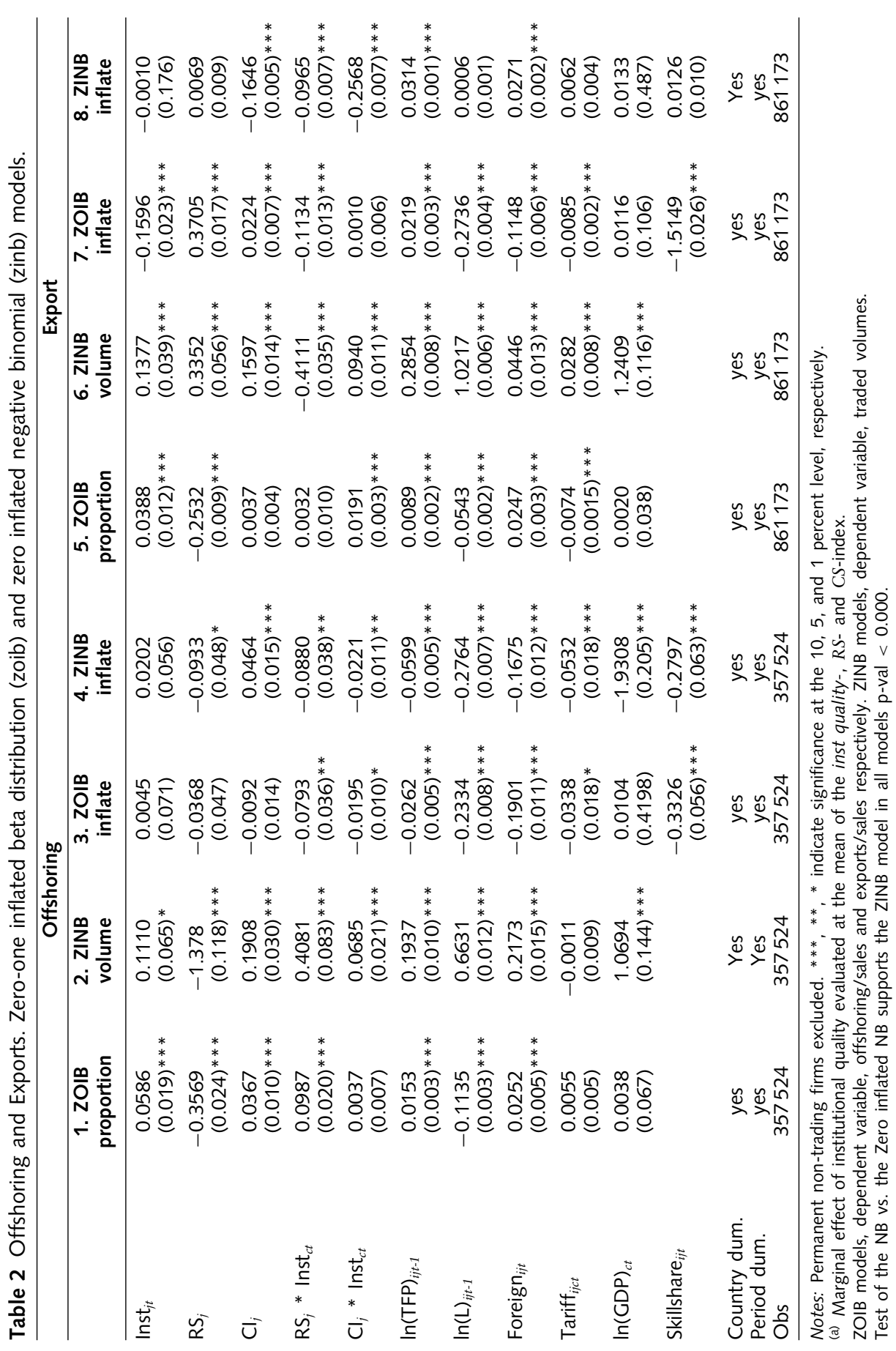


tion terms, the marginal impact of institutions on trade is not constant over the observed span of the two indices. Figure 3 shows that the marginal impact of institutions increases with the value of both the RS-index and the CI-index. For exports, the impact of intuitions is increasingly positive and significant for all values of the CI and RS-indices. For offshoring, we see that the marginal effect of institutions becomes significant at higher values of relationship-specificity, but that it never reaches significance in the CI-dimension. These results highlight the possibility of misleading results when evaluating the effect of institutions at a specific value of the RS or CI-index.

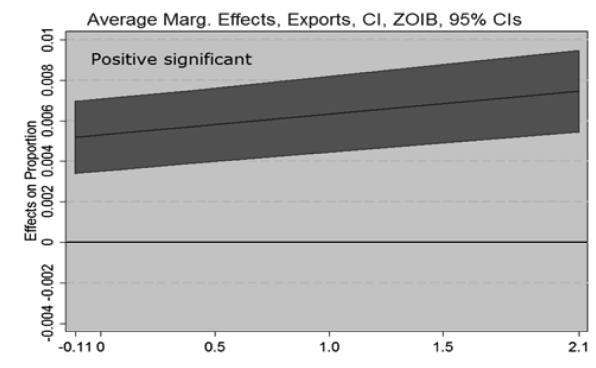

Offshoring CI-index

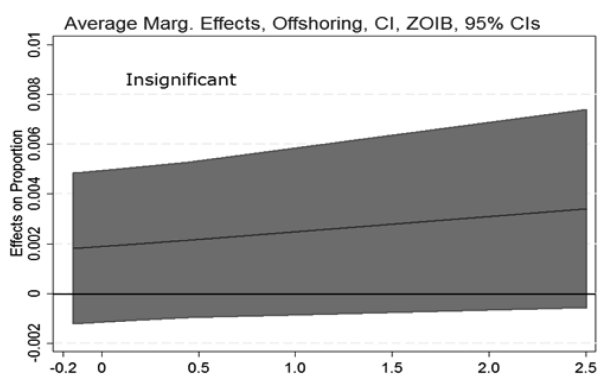

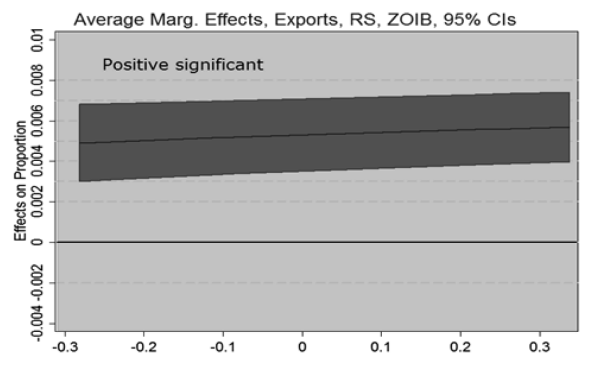

Offshoring RS-index

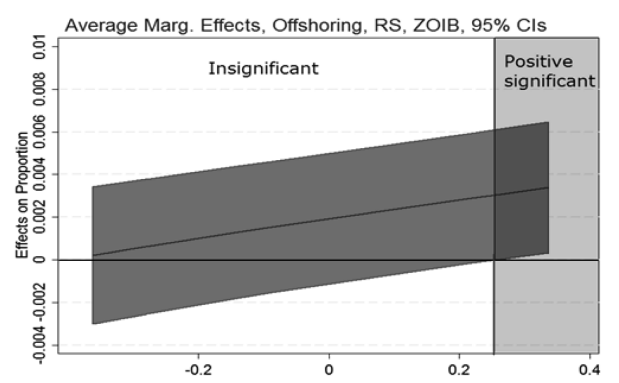

Note: The $\mathrm{Cl}-$ and RS-indices are centered around the mean.

Figure 3 The marginal effect of institutions for different values of the $\mathrm{Cl}$ - and RS-index

Returning to Table 2, it can be noted that the results for the extensive margin of trade (the selection estimations) are not as clear as those for the intensive margin. The logit inflation step in the ZINB model yields an insignificant direct effect of institutional quality, but negative interaction effects with RS and CI in both the offshoring and export estimations. In addition, we would expect the zero inflation step in the ZOIB model, which estimates the likelihood of observing zero-valued trade flows, to generate coefficients with the opposite signs compared to the ZINB inflation step. However, this is not always the case. The lack of consistent results precludes clear-cut predictions regarding the interplay between institutional quality and the RS and CI-indices for the selection estimations. One reason could be that the extensive margins have remained relatively stable throughout the crisis period, with little systematic variation. As pointed out above, this is also the reason why we focus on the intensive margins of trade in the current analysis. 


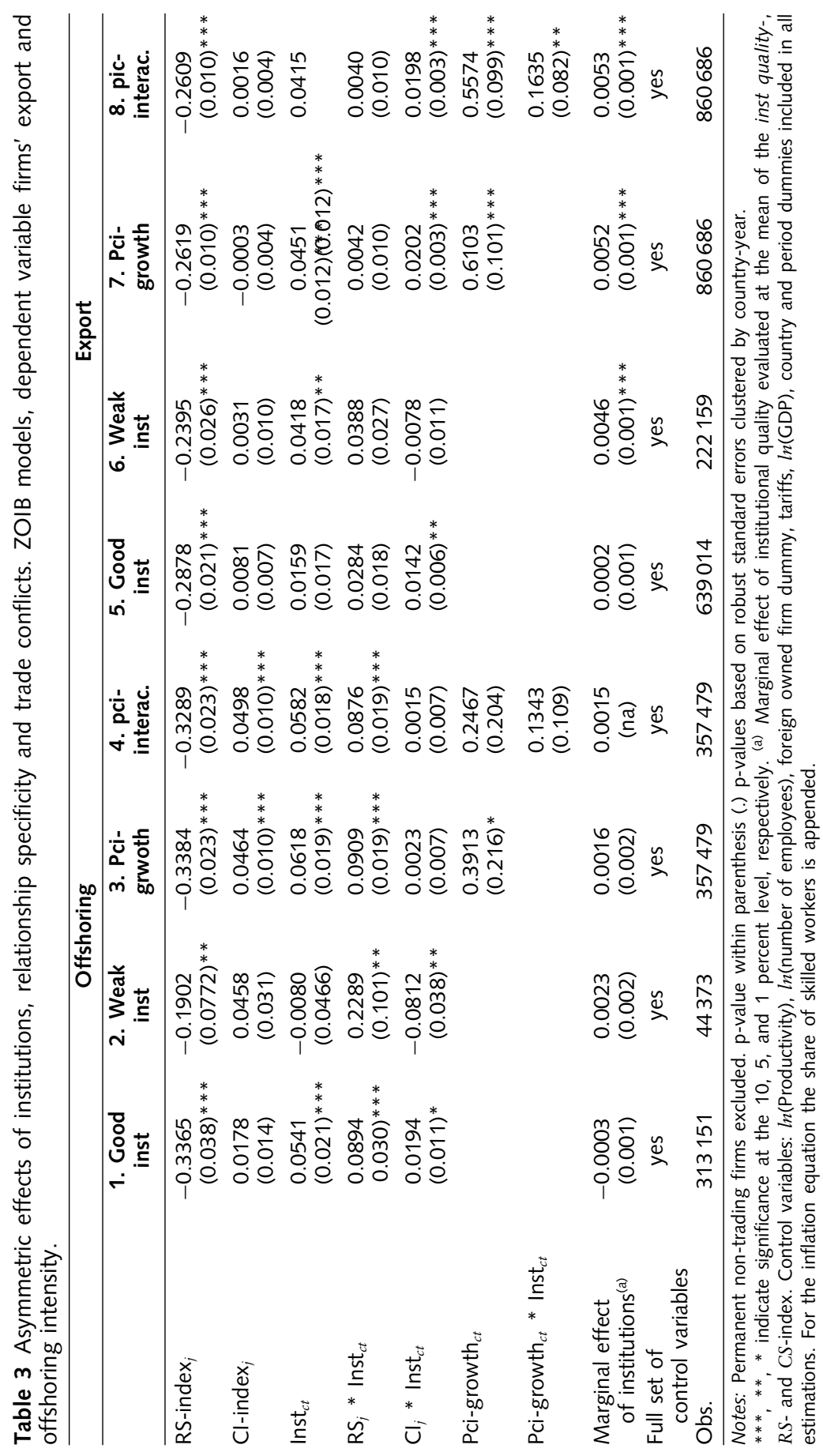


In summary, the results from Table 2 show that institutions, relationship-specificity, and conflict risk have a systematic effect on the extensive margins of exports and offshoring. A weak institutional environment hampers exports and offshoring in general, and in particular exports in conflict-intensive sectors and offshoring in relationship-specific sectors. Translating these findings into a context where the role of non-OECD economies is expected to increase further suggests that many firms may find it difficult to restructure their export relationships. The institutional environment in many non-OECD countries is weaker, which suggest that there is a higher threshold for engaging in trade. In particular, there is reason to expect that industries recording high values for the CI-index (RS-index) may find it hard to shift their exports (offshoring) from OECD to non-OECD countries. Some changes in the structure of trade can therefore be expected, at least during a transition period while firms learn to navigate new institutional environments.

Tables 3-6 explore some extensions and test the robustness of the findings stated above. In Table 3, we explore some of the asymmetries between OECD and non-OECD countries in closer detail. More specifically, we analyze how the effect of institutions and related variables vary across countries with different levels of institutional quality and economic growth. Columns 1-2 (for offshoring) and 5-6 (for exports) compare countries with different levels of institutional quality. Countries are classified in the "good institutions" group if their value for the variable Inst ${ }_{c j}$ is above average and in the "weak institutions" group otherwise. Columns 3-4 (for offshoring) and 7-8 (for exports) examine the link between economic growth, trade, and institutions. The question here is whether differences in institutional quality have any influence on the expected trade-promoting impact of high growth rates in the partner country.

A first point to note from columns $1-2$ and $6-7$ in Table 3 is that the marginal impact of institutional quality is larger in countries with lower-than-average institutional quality than in countries with well-developed institutions. This asymmetry between country groups is statistically significant for exports, but not for offshoring.

A second notable point is that the inclusion of per capita income growth in the destination market has a strongly significant and positive impact on exports (column 7), but a weaker and less significant effect on offshoring (column 3). Columns 4 and 8 explore the impact of growth further by appending an interaction term between income growth and institutional quality ( $p c i$ growth $c t$. Inst $c t$ ). It can be seen that there are no systematic asymmetric effects of income growth on offshoring, while exports to high growth economies are boosted by strong institutions. This means that exports are drawn to growing economies in general but that weak institutions hamper this reallocation. For offshoring, it should be noted that income growth has two opposite effects that may cancel each other. On the one hand, income growth and development are expected to raise the variety of products available for offshoring, suggesting a positive effect. On the other hand, high growth is associated with increasing wages and prices, which could have a negative impact on offshoring.

\subsection{Robustness: varying the multilateral trade resistance term}

To capture the effects of relative prices on trade patterns and to overcome the omitted variable bias, the specification of the multilateral trade resistance term plays a central role in the estimation of gravity models (Anderson/van Wincoop 2003; Feenstra 2004). To analyze the robustness of the results with respect to various specifications of the MTR term, Table 4 presents results with different dummy variable set-ups. In columns 1 (offshoring) and 5 (exports), we introduce industry dummies at the two-digit level. These 


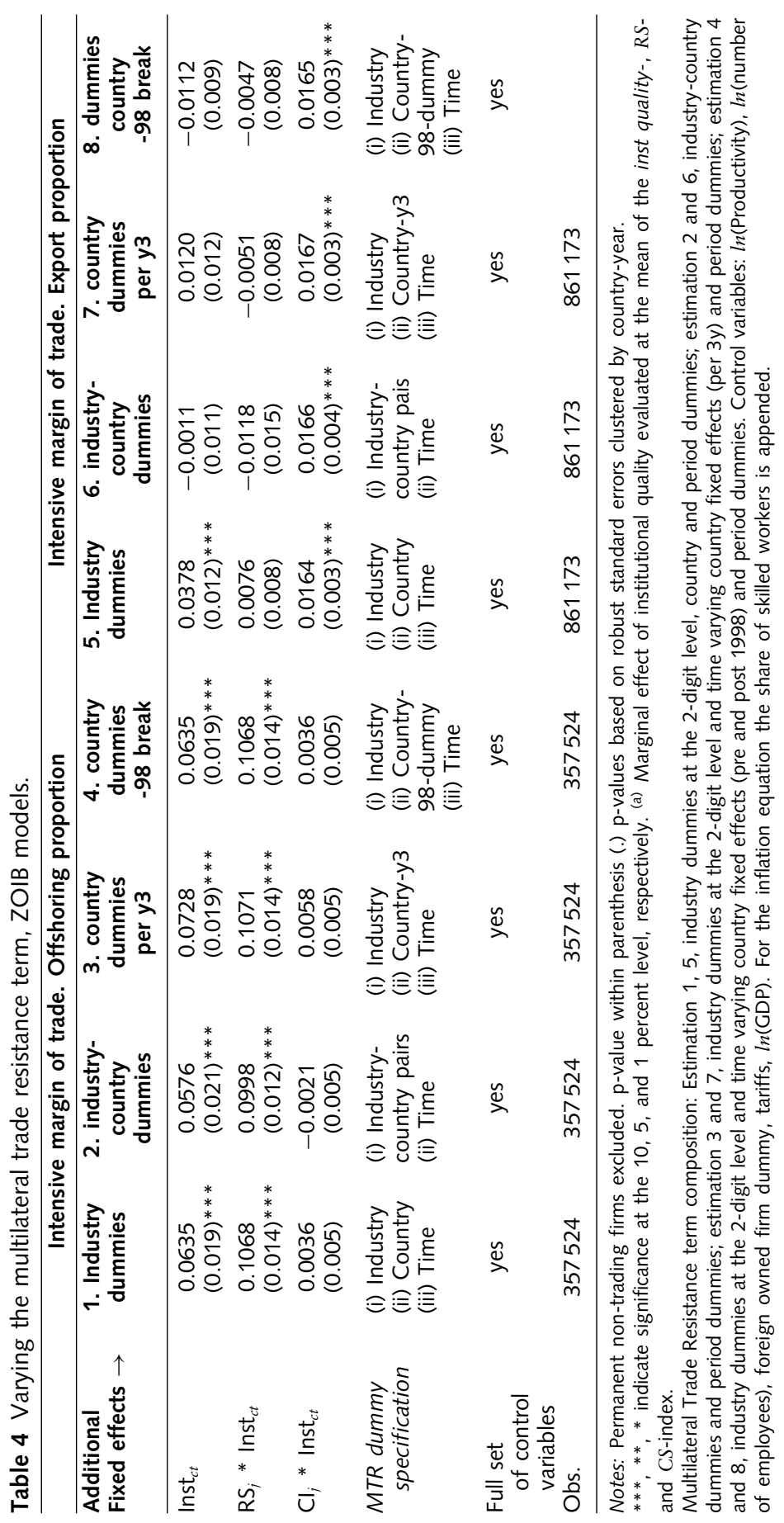


dummies make the time invariant RS- and CI-indices redundant.${ }^{16}$ However, introducing industry dummies does not affect the results for the role of institutions and the interaction between institutions and industry characteristics.

To further investigate industry-country heterogeneity, columns 2 (offshoring) and 6 (exports) allow for industry-country specific dummies. This means that we add 4,048 dummies (22 industries * 184 country dummies) to the model. Despite the large number of dummy variables added, the results remain almost unchanged. These estimations suggest that our results are robust with respect to fixed effects in the industry-country dimension.

To control for changes in relative prices, columns 3-4 (offshoring) and 7-8 (exports) introduce time-varying country dummies. In columns 3 and 7, we allow the country dummies to change every three year, allowing for non-constant relative prices. In addition, to check whether results are robust with respect to the pre- and post-crisis years, in columns 4 and 8 , we split the country dummies in two groups, before and after 2008, the year of the financial crisis. Again, we find the results to be remarkably robust with respect to the inclusion of these fixed effects. The results strengthen our main findings, namely that strong institutions are of particular value for offshoring in relationship-specific industries and exports in conflict-intensive industries.

\subsection{Robustness: the impact of previous internationalization experience}

The CI-index is designed to capture the industry-specific risk of trade conflicts. To take into account the fact that it is more likely to observe a conflict in an industry where large volumes of goods are transacted, we weight the CI-index with the relative size of the industry trade flows. If the industry's total trade flows are exogenous to the firm, this weighting scheme is unproblematic, but there might be a risk that industry aggregates are not exogenous to the firm and therefore impose an endogeniety problem. To analyze the sensitivity of results with respect to the weighting scheme of the CI-index, columns 1 and 5 in Table 5 estimate offshoring and export models with an unweighted CI-index. Applying the unweighted CI-index changes the size of the estimated coefficients, but does not change the sign or significance of the results. Specifically, using the unweighted CI-index reduces the coefficient for the interaction term $\left(\mathrm{CI}_{j} \cdot \mathrm{Inst}_{c t}\right)$ in the export equation and leaves its significance (at the 0.001 level) intact. For the offshoring equation, the interaction term $\left(C I_{j} \cdot I_{n s} t_{c t}\right)$ remains insignificant with the unweighted CI-index, suggesting that the results are not dependent on a specific weighting scheme.

Earlier analyses of Swedish trade have shown that about 40 percent of all new Swedish export flows are terminated after one year, while about 15 percent last for six years or more. It is also known that trade flows increase rapidly during the first two to three years of the trade relationship, leveling out thereafter (Söderlund/Tingvall 2014). Hence, previous export (offshoring) status can be an important predictor of current export (offshoring) flows (Roberts et al. 2012). In Table 5, columns 2-4 (offshoring) and columns 6-8 (exports) include lagged offshoring or export status as a predictor of trade. The results confirm that previous trade status is a highly significant predictor of current trade flows, providing a partial explanation for why the adjustment to the crisis has mainly occurred

\footnotetext{
${ }^{16}$ Due to a new industry classification scheme in 2007 (SNI 2002 to SNI 2007), there is a one-period spike where some industries do not match perfectly into the old industry classification scheme. The RS and CI-indices are defined on the basis of the 2002 classification,
} 


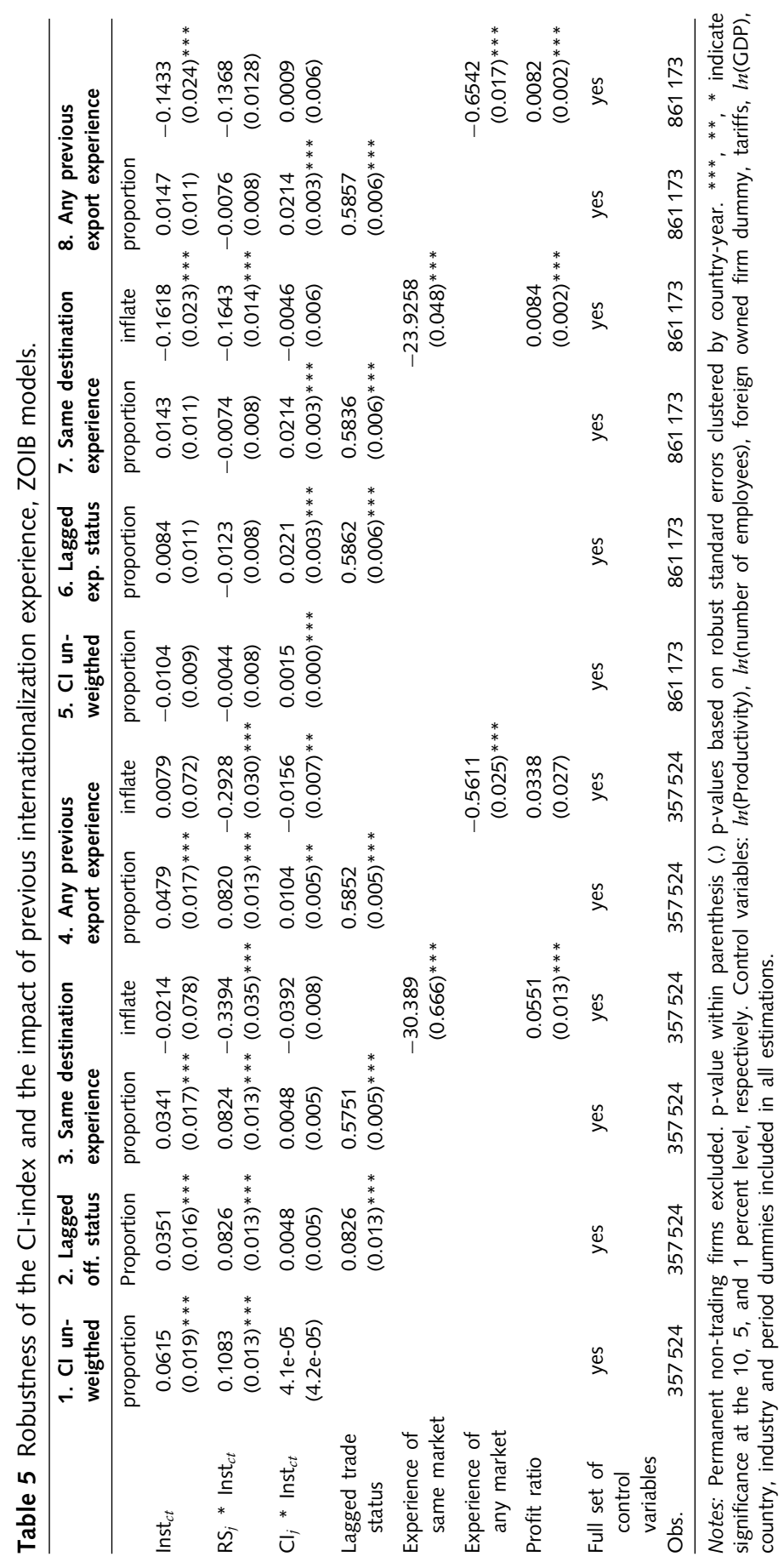


at the intensive margin: firm level trade flows are sticky. It can also be seen that adding lagged trade status in the volume equations does not upset our main findings regarding the interactions between institutional quality, relationship-specificity, and conflict-intensity. In the inflation equations in Table 5, we have replaced the skill share of the firm with the firm's profit margin, as an additional robustness test. The underlying argument is that foreign market entry is costly and that that it should be easier for profitable firms to handle the costs related to international expansion. Somewhat surprisingly, the results in Table 5 suggest that high profit margins reduce the odds of internationalization. One explanation for this unexpected result could be that the costs of foreign market entry are likely to reduce current profits. As discussed earlier, the costs for export market entry and selection into offshoring can be seen as fixed costs that the firm has to overcome in order to become internationalized (Melitz 2003).

An important question in this context is whether the entry costs related to new markets can be reduced through experience and learning, and if so, whether the relevant experience is market specific or generalizable to all markets. Using information on past market experience allows us to probe this question in some detail. Specifically, in columns 3 (offshoring) and 7 (exports) we have adjusted the zero inflation step by adding a dummy variable that takes the value one if a firm has previous market experience from the same country (a previous trade spell) and the value zero otherwise.

The zero inflation step focuses on the odds for observing zero-valued trade flows. The negative sign for previous market experience therefore suggests that if a firm has exported to a specific country (has been offshoring) it is less likely a country at some point in the past (been offshoring from a country in the past) it is less likely to record zero-valued exports (offshoring) in the current period. Hence, previous experience from a foreign market raises the likelihood of re-entry. In columns 4 and 8 we proceed by examining whether previous experience of exports to (offshoring from) any country increases the odds for participation in international exchange. The results confirm that previous market experience has a significant impact on firms' decisions to participate in international trade. Firms that have previous export experience (offshoring experience) are more likely than other firms to engage in new export (offshoring) transactions. It can be noted that the coefficient for experience from the same market (previous spells of offshoring or exports) is larger and more significant than the variable capturing the role of previous spells of offshoring from or exports to any market. This suggests that the cost of market entry to some extent is market specific, and that there could be learning effects that eventually reduce the costs of entering markets that are initially unfamiliar.

\subsection{Robustness: the link between exports and offshoring}

It is a well-known fact in international trade that the majority of trading firms are two-way traders, meaning that exporters also engage in imports - to become competitive in foreign markets, firms need to source their intermediate products from the most cost-efficient sources, some of which are likely to be located outside their home country. In a Swedish context, it has been shown that the vast majority of persistent exporters also engage in imports, and that non-importing firms are overrepresented among non-exporters (Jienwatcharamongkhol 2014). Further supporting evidence of a two-way interdependence between exports and imports is presented by e.g. Kasahara and Lapham (2013) and Aristei et al. (2013). Navas et al. (2013) present theoretical arguments for a two-way relation by pointing to how imports enhance firm-level productivity, which in turn promotes 


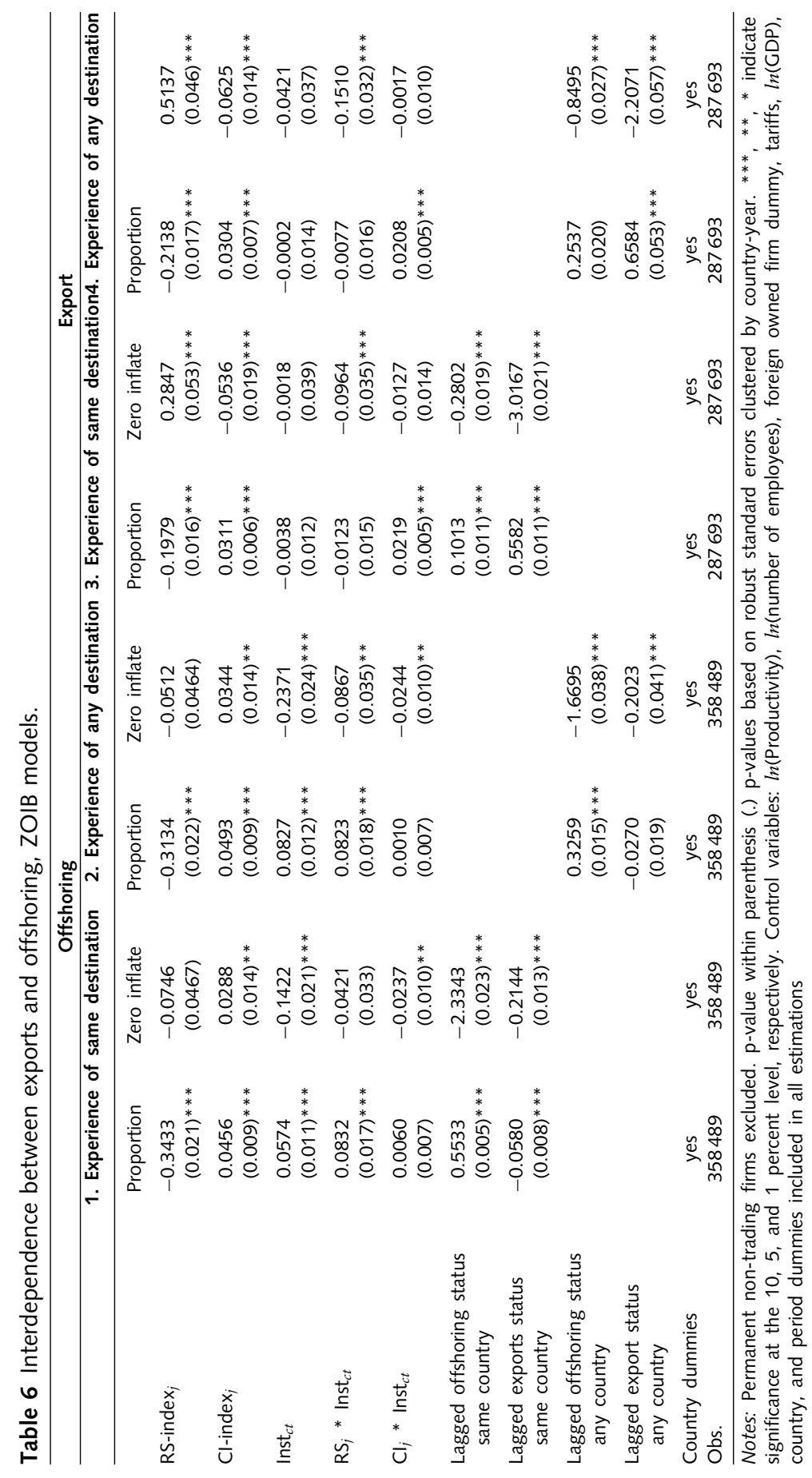


exports. In Table 6, we add to the growing body of literature on the export-import nexus by analyzing how lagged export and offshoring status influence current trade flows. ${ }^{17}$

The results regarding past export / offshoring status in Table 6 can be summarized as follows. Starting with exports, we see that both lagged export and offshoring status have a positive and significant impact on current exports. However, lagged export status is a stronger predictor of current exports than lagged offshoring status. In addition, experience from the same market has a larger impact on exports than experience of just any market. A similar pattern holds for offshoring: previous offshoring status is more relevant than previous export status. In fact, in column 1, we even find a negative and significant relation between current offshoring and lagged export experience from the same market. In other words, the decision to offshore to a specific destination does not seem to be based on experience from previous exports to that market. Broadening the question to cover previous experience from any market makes the relation between current offshoring and lagged export status insignificant. These results suggest that the impact of past offshoring experience on export performance is stronger than the opposite effect. A similar pattern applies when we look at the zero inflation step in the ZOIB estimations.

These finding suggests that firms typically do not start offshoring from a specific country because of experiences gained from past exports to the same country, but that past offshoring may trigger the firm to start exporting to the former source country. Moreover, past experience of the same country is a stronger predictor for market participation than are lagged engagements with any country. This indicates that firms with prior experience may have been able to learn about internationalization in general, and that the entry barriers for firms with past experience of a specific market may be lower than the entry barriers for firms without such country-specific experience. At the same time as these findings are noted, it should also be stressed that our main findings regarding the role of institutional quality are not affected much. Even taking into account lagged internationalization status, the results suggest that exports in conflict-intensive industries are enhanced by strong institutions in target economies and that strong institutions enhance offshoring in relationship-specific industries.

\subsection{Duration}

Apart from the impact of institutions on the selection of trade partners and trade volumes, it is also possible that institutions may influence the duration of trade spells. In new and uncertain markets, we expect to see relatively short-lived trade flows (Aeberhardt et al. 2011; Araujo et al. 2012; Söderlund/Tingvall 2014). Figure 4 graphs descriptive statistics on the survival probability of trade flows with respect to different firm and country characteristics. More precisely, Figure 4 shows that trade relations with countries with weak institutions are relatively short-lived, but that income growth is beneficial for trade survival. It can also be seen that the duration of trade spells increases with firm size. These patterns hold for exports as well as for offshoring.

Table 7 presents the results of a duration analysis that allows us to explore trade survival in closer detail. Column 1 presents a basic model for export survival, columns 2-3 explore non-linearities in the impact of institutional quality, and columns 4-6 contain separate

\footnotetext{
${ }^{17}$ Contrary to section 5.3 where used previous trade experience (from any earlier time period), section 5.4 applies lagged export and offshoring status.
} 

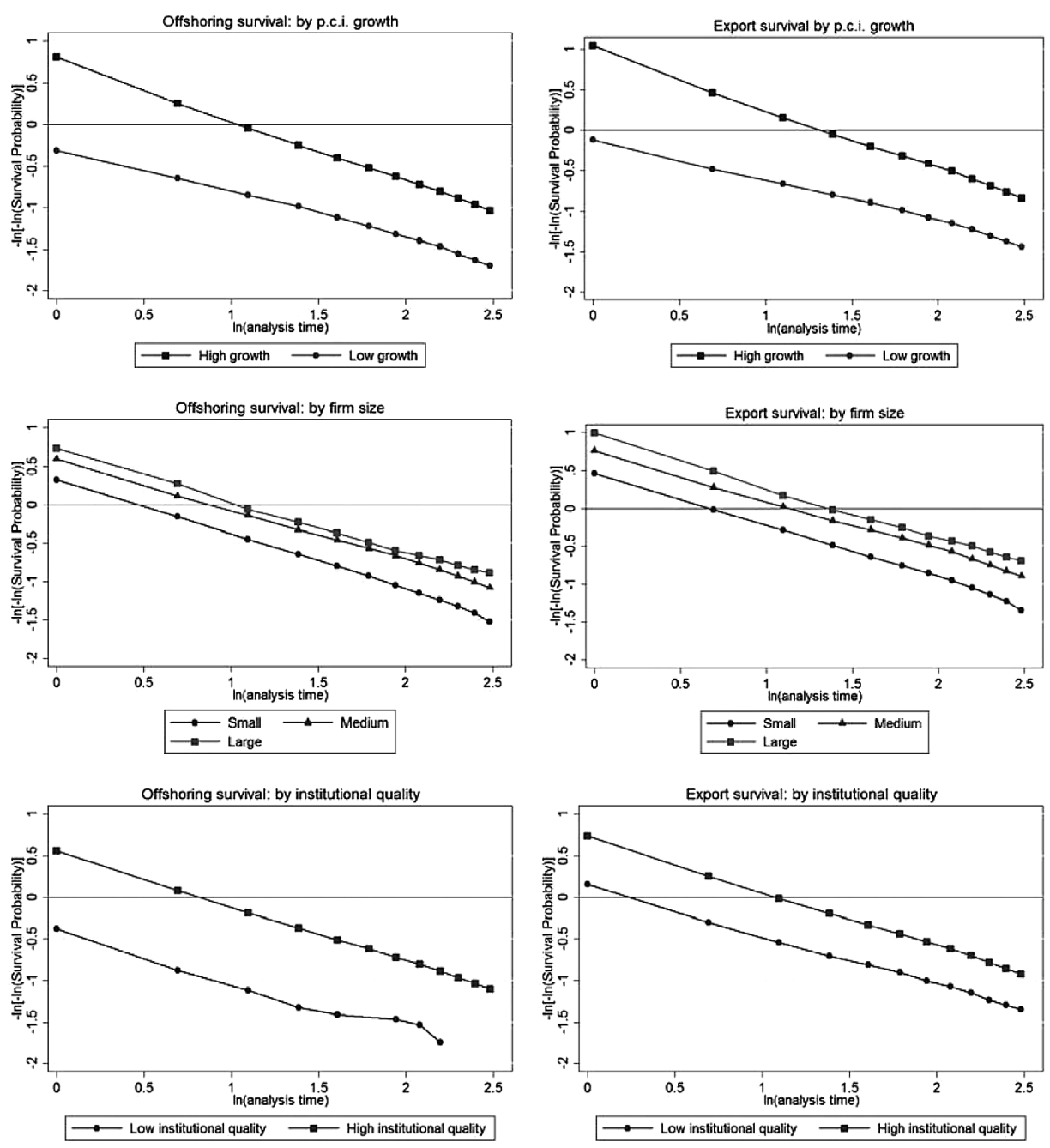

Figure 4 Trade survival. By firm size, institutional quality, and income growth

estimations for small, medium-sized, and large firms. Columns 7-12 repeat the exercise for durations of offshoring flows. The impact of per capita income growth on spell length is included in all estimations in Table 7. The table presents the coefficients for the hazard rate. A coefficient larger (smaller) than unity suggests an increase (decrease) in hazard rates.

The estimation results in Table 7 confirm the patterns shown in Figure 4. First, a stronger institutional environment reduces the hazard of exit for both exports and offshoring. In all models, both the direct impact and the marginal impact of institutions indicate that better institutions increase trade survival. The only exception is exports to countries with strong 


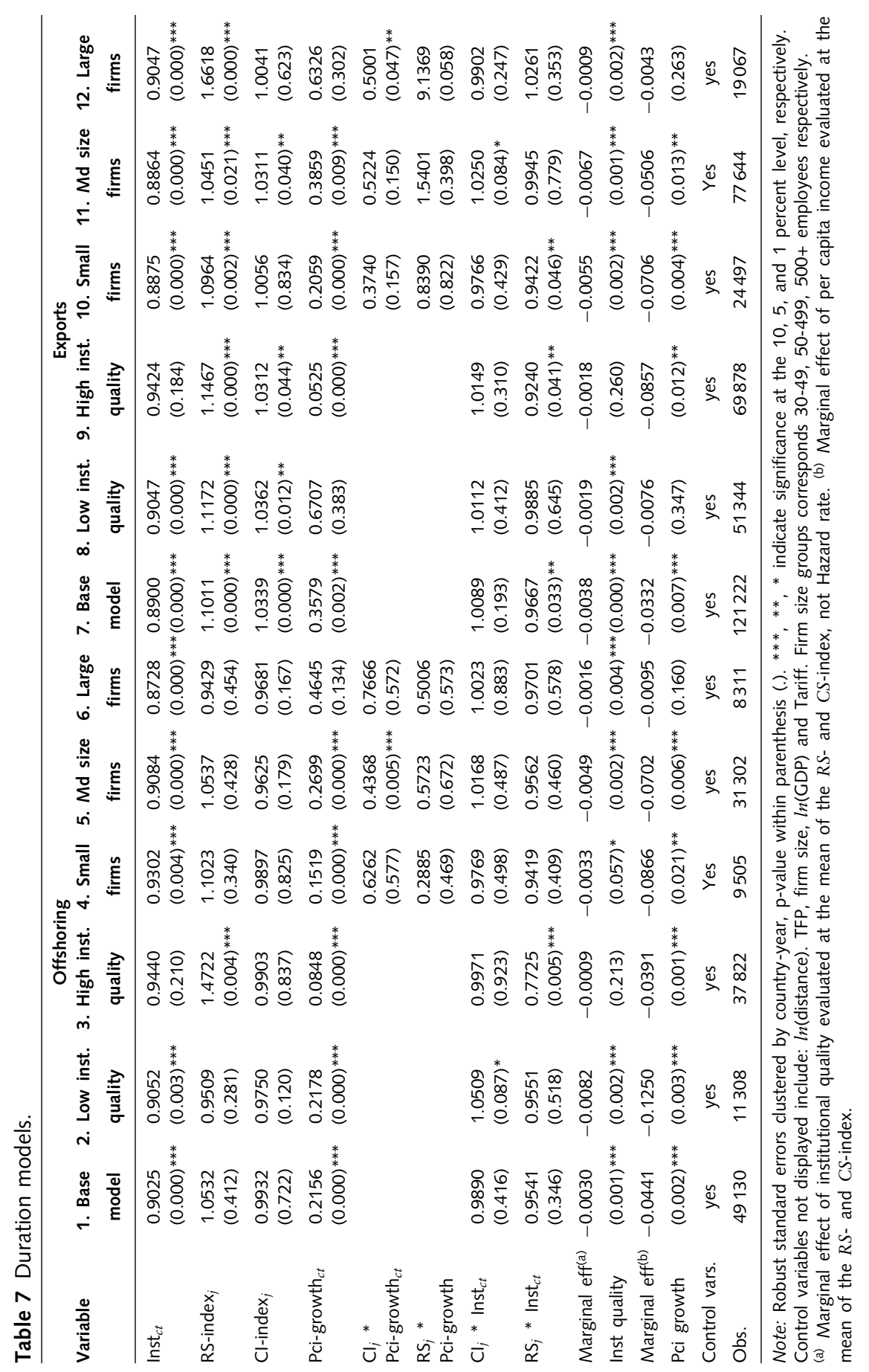


institutions. The impact of institutions on survival is particularly strong for countries with relatively weak institutions. Higher values for the RS- and CI-indices tend to raise the exit hazard for exports, while the estimated effects for offshoring are mostly insignificant. The asymmetry imposed by industry differences in the RS and CI-dimensions and their interaction with institutional quality is not as pronounced for trade survival as for the intensive margin of trade. For offshoring, the interaction between institutional quality and the RS- and CI- indices is insignificant and does not appear to influence trade survival to any great extent. For exports, the results suggest that good institutions have a stronger impact on trade survival in relationship-specific industries.

A clear result is that growth rates matter. The estimated coefficient for the direct impact of per capita income growth is well below one and highly significant in most of the estimations. This means that the exit hazard is lower in countries where the growth rate is higher. The same result is obtained when we look at the marginal effect of per capita income growth on trade survival. The marginal effect of per capita income growth is evaluated at the mean values of the RS and CI-indices, taking into account not only the direct effect of growth but also the interactions between PCI-growth and the RS and CI-indices. The coefficient shows the impact on the exit rate: higher growth rates reduce exit rates in all estimations except the one for offshoring and exports by the largest firms (columns 6 and 12) and exports in the most difficult export markets (column 8). The finding that higher growth rates do not reduce the exit hazard in the group of countries with the weakest institutional quality is notable, and highlights the challenges faced by exporters trying to redirect trade from stagnant OECD markets to rapidly growing emerging markets. Higher growth rates do not always make up for the entry barriers caused by weak institutional quality. It can also be noted that the impact of growth seems to be rather homogenous across industries with respect to the RS and CI-indices.

Another tendency found in Table 7 is that the effects of institutional quality and growth on trade survival are not identical across different firm size categories. Generalizing, the results indicate that smaller exporting firms are more sensitive to the effects of institutions and growth - the reduction in the exit hazard that follows from a good institutional environment and high economic growth is larger for the small firm category than for larger firms. In the case of offshoring, the impact of institutional quality does not differ much between the firm size categories.

The main conclusions from Table 7 are that institutions matter for the survival and duration of trade relationships, but that there is also a strong impact of economic growth, especially for smaller firms. Considering the expected shift in trade structure towards non-OECD markets, this suggests partly off-setting effects. Several of the important nonOECD markets are characterized by relatively weak institutional environments, and can be expected to post relatively high growth rates in the medium term future. An optimistic interpretation and projection is that the growth prospects in these countries provide the motives for Western firms to invest in learning about the institutional environment. As long as high growth rates and prospects for future sales expansion justify the necessary investments, it is possible that even relatively small firms will be able to expand their presence in the non-OECD region. However, a substantial reduction in non-OECD growth rates would change the picture dramatically. 


\section{Summary and conclusions}

A major feature o the 2008-09 financial crisis was the dramatic collapse in world trade. During the last quarter of 2008 and the first quarter 2009, world GDP fell by approximately three percent, while world trade declined by almost 30 percent. While the crisis led to a sustained reduction in aggregate demand in Western Europe and North America, there were several emerging markets that managed to recover quickly and post stable growth figures soon after the crisis. As a result, aggregate demand shifted away from the traditional OECD markets toward new emerging non-OECD markets. It is not likely that the increasing importance of non-traditional markets is a temporary phenomenon instead, most long-term projections suggest that their market shares will increase further in the future.

The shift from traditional Westerns markets to new markets largely outside the OECD poses many challenges for European companies. The maybe most challenging task for firms engaged in exports and offshoring is related to dealing with an unfamiliar institutional environment. The institutional barriers that have to be overcome to successfully enter new markets range from knowledge about rules and regulations to cultural aspects of business conduct. Yet, little is known about how the large institutional differences between Europe and emerging markets in general may come to influence the determinants and patterns of European trade.

Using Swedish firm-level data for the period 1997-2009, we explore the consequences of the increasing role of non-OECD countries in international trade. A main concern is how cross-country differences in economic growth and institutional quality affect exports and offshoring. In particular, we focus on the interaction between institutional quality in target economies and sectoral differences in trade conflicts and buyer-seller relations. For this purpose, we introduce a new index of conflict-intensity, which identifies sectors where the risk of trade disputes is particularly high. Industry differences in buyer-seller interactions are captured using the Nunn (2007) index of relationship-specificity.

The results from this study suggest that exports are attracted to rapidly growing markets, but there are no signs of any corresponding growth effect for offshoring. That is, trade in general and exports in particular have been diverted from the OECD region toward rapidly growing non-OECD economies. However, non-OECD economies generally exhibit a lower institutional quality than the traditional OECD markets, which hampers the growth-driven redirection of trade.

When trade shifts toward countries with relatively weak institutions, the impact of institutional quality is not symmetric across goods and industries. Exports of goods exhibiting high conflict-intensity are particularly challenged by weak institutions in target economies. For offshoring, the degree of relationship-specificity seems to be of importance, while conflict-intensity matters less. Taking into account the seller-buyer engagements that offshoring often requires, the relatively high sensitivity of relationshipspecificity is expected. Examples of goods that rank high in relations-specificity and that will be the most difficult to redirect toward non-OECD markets include professional and scientific equipment and transport equipment, whereas goods that do not require much seller-buyer interactions, such as non-ferrous metals and petroleum refineries, are less affected by institutional quality. Looking at conflict intensity, the industries with the highest values for our CI-index are pharmaceutical products, iron and steel, and motor vehicles, whereas there are no conflicts recorded in the WTO dispute settlement body in goods such as jewelry, toys, sports equipment and wood products. 
Our findings also indicate that trade relations with countries that have weak institutions are characterized by relatively short-lived trade spells. The problem of upholding long-lived trade relations with partners located in markets with weak institutions is most serious for small firms that are particularly sensitive to uncertainty and high trade costs. Hence, the reshaping of global trade patterns has asymmetric effects on exports and offshoring, and both trade flows and the duration of trade are hampered by weak institutions. These findings suggest that shifting trade toward non-OECD countries will necessitate industrial restructuring and that small firms will face particular challenges related to the institutional environment in emerging markets. Considering that knowledge about foreign institutional environments to some extent is a public good, this may motivate coordinated investments in learning and information sharing among small firms. It is also possible that the problems related to trade with partner countries with weak institutions will diminish over time. One reason suggested by our results is that some learning seems to take place as firms cumulate international experience and knowledge about specific foreign markets - although the first ventures into new markets are likely to be problematic, our results suggest that there are learning effects that make subsequent efforts easier and more successful. Another reason is the gradual improvement in institutional quality that takes place in most non-OECD economies. Although the analysis focuses on Sweden, the results are generalizable to many other developed countries. Most of the OECD economies will face similar changes in their trade structure in the coming years.

\section{References}

Aeberhaedt, R., I. Buono, H. Fadinger (2011), Learning Incomplete Contracts and Export Dynamics: Theory and Evidence from French Firms. Vienna Economics Papers 1006, University of Vienna, Department of Economics.

Altomonte, C., G. Békés (2010), Trade Complexity and Productivity. CeFiG Working Papers 12, Center for Firms in the Global Economy, revised 25 Oct 2010.

Anderson, J.E., D. Marcouiller (2002), Insecurity and the Pattern of Trade: An Empirical Investigation. Review of Economics and Statistics 84(2): 342-352.

Anderson, J.E., E. Wincoop (2003), Gravity with Gravitas: A Solution to the Border Puzzle. American Economic Review 93(1): 170-192.

Antràs, P. (2003), Firms, Contracts, and Trade Structure. Quarterly Journal of Economics 118(4): 1375-1418.

Araujo, L., G. Mion, E. Orneals (2012), Institutions and Export Dynamics. CEPR Discussion Paper 8809. London: Centre for Economic Policy Research.

Awokuse, T.O., H. Yin (2010), Does Stronger Intellectual Property Rights Protection Induce More Bilateral Trade? Evidence from China's Imports. World Development 38(8): 1094-1104.

Baldwin, R. (ed.) (2009), The Great Trade Collapse: Causes, Consequences and Prospects. CEPR. (available online at http://www.voxeu.org/index.php?q=node/4297).

Bartel, A., S. Lach, N. Sicherman (2005), Outsourcing and Technological Change. NBER WP. No. 11158.

Behrens, K., G. Corcos, G. Mion (2013) Trade Crisis? What Trade Crisis? Review of Economics and Statistics 95(2): 702-709.

Belloc, M. (2006), Institutions and International Trade: A Reconsideration of Comparative Advantage. Journal of Economic Surveys 20(1): 3-26.

Bénassy-Quéré, A., Y. Decreux, L. Fontagné, D. Khoudour-Castéras (2009), Is Trade the Victim of Globalisation? La Lettre du CEPII, CEPII research center, issue 291.

Bergstrand, J.H. (1990), The Heckscher-Ohlin-Samuelson Model, the Linder Hypothesis and the Determinants of Bilateral Intra-industry Trade. Economic Journal 100(403): 1216-1229. 
Bernard, A., J.B. Jensen (2004), Why some firms export. Review of Economics and Statistics 86(2): 561-569.

Bernasconi, C. (2009) New evidence for the Linder Hypothesis and the two extensive margins of trade. Mimeo, University of Zurich, February.

Casaburi, L., V. Gattai (2009), Why FDI? An Empirical Assessment Based on Contractual Incompleteness and Dissipation of Intangible Assets. Working Papers 164, University of Milano-Bicocca, Department of Economics.

Chor, D., K. Manova (2010), On the cliff and back? Credit conditions and international trade during the global financial crisis. Technical report, NBER Working Paper, 16174.

Colin, C.A., P.K. Trivedi (2009), Microeconometrics using stata. College Station, TX: Stata Press.

CPB World Trade MONITOR (2014), Netherlands Bureau for Economic Policy Analysis. http://www.cpb.nl/en/world-trade-monitor.

Disdier, A-C., K. Head (2008), The Puzzling Persistence of the Distance Effect on Bilateral Trade. The Review of Economics and Statistics 90(1): 37-48.

Evenett, S.J. (2009), Crisis-era protectionism one year after the Washington G20 meeting. In: R. Baldwin (ed.), The Great Trade Collapse: Causes, Consequences and Prospects. CEPR. available at http://www.voxeu.org/index.php?q=node/4297).

Feenstra, R.C. (2004), Advanced International Trade: Theory and Evidence. Princeton and Oxford: Princeton University Press.

Ferguson, S., S. Formai (2013), Institution-Driven Comparative Advantage, Complex Goods and Organizational Choice. Journal of International Economics 90(1): 193-200.

Ferrari, S.L.P., F. Cribari-Neto (2004), Beta regression for modelling rates and proportions. Journal of Applied Statistics 31(7): 799-815.

Grossman, S.J., O.D. Hart (1986), The Costs and Benefits of Ownership: A Theory of Vertical and Lateral Integration. Journal of Political Economy 94(6): 691-719.

Grossman, G., E. Rossi-Hansberg (2012), Task Trade Betweeen Similar Countries. Econometrica 80(2): 593-629.

Hallak, J.C. (2010), A product-quality view of the Linder hypothesis. The Review of Economics and Statistics 92(3): 453-466.

Hart, O., J. Moore (1990), Property Rights and the Nature of the Firm. Journal of Political Economy 98(6): 1119-1158.

Hijzen, A. (2005), A bird's eye view of international outsourcing: data, measurement and labour demand. Economie Internationale 104: 45-63.

Horn, H., L. Johannesson, P.C, Mavroidis (2011), The WTO Dispute Settlement System 1995-2010: Some Descriptive Statistics. Journal of World Trade 45(6): 1107-1138.

Jienwatcharamongkhol, V. (2013), What Drives Exports? Empirical Evidence at the Firm Level. Ph.D Thesis, Lund Economic Studies Number 177.

Johanson, J., J.E. Vahlne (1977), The internationalisation process of the firm - A model of knowledge development and increasing market commitment. Journal of International Business Studies 8(1): 23-32.

Johanson, J., F. Wiedersheim-Paul (1975), The internationalization of the firm: Four Swedish cases. Journal of Management Studies 12(3): 305-322.

Kasahara, H., B. Lapham (2013), Productivity and the decision to import and export: Theory and evidence. Journal of International Economics 89(2): 297-316.

Kaufmann, D., A. Kraay, P. Zoido-Lobatón (1999), Aggregating Governance Indicators. World Bank Policy Research Working Paper Series 2195.

Koenig, P., F. Mayneris, S. Poncet (2010), Local export spillovers in France. European Economic Review 54(4): 622-641.

Kokko, A., P. Gustavsson Tingvall (2014), Distance, Transaction Costs, and Preferences in European Trade. Forthcoming, International Trade journal.

Kukenova, M., M. Strieborny (2009), Investment in Relationship-Specific Assets: Does Finance Matter? MPRA Paper 15229, University Library of Munich, Germany.

Levchenko, A. (2007), Institutional Quality and International Trade. Review of Economic Studies 74(3): 791-819. 
Levchenko, A.A., L.T. Lewis, L.L. Tesar (2010), The Collapse of International Trade During the 2008-2009 Crisis: In Search of the Smoking Gun. NBER Working Paper Series, No. 16006.

Linder, S. (1961), An Essay on Trade and Transformation. Stockholm: Almqvist \& Wicksell.

Long, J.S., J. Freese (2006), Regression Models for Categorical Dependent Variables Using Stata. (Second Edition). College Station, TX: Stata Press.

Márquez-Ramos, L., I. Martínez-Zarzosa, C. Suárez-Burguet (2012), Trade Policy versus Institutional Trade Barriers: An Application Using "Good Old" OLS. Economics: The OpenAccess, Open-Assessment E-Journal 6(11): 1-38.

Massini, S., N. Pern-Ajchariyawong, A.Y. Lewin (2010), Role of corporate-wide offshoring strategy on offshoring drivers, risks and performance. Industry and Innovation 17(4): 337-371.

Mayer, T., S. Zignago (2006), Notes on CEPII's distance measures. MPRA Paper 26469.

Méon, P., K. Sekkat (2006), Institutional quality and trade: Which institutions? Which trade? DULBEA working paper 06-06.RS, Universite libre de Bruxelles.

Navas, A., F. Serti, C. Tomasi (2013), Intermediate Inputs and the Export Gravity Equation. The University of Sheffield, Department of Economics Working Papers No. 2013014.

North, D.C. (1991), Institutions. Journal of Economic Perspectives 5(1): 97-112.

Nunn, N. (2007), Relationship-Specificity, Incomplete Contracts, and the Pattern of Trade. Quarterly Journal of Economics 122(2): 569-600.

OECD (2012), Looking to 2060: Long-Term Global Growth Prospects. OECD Economic Policy Papers, No. 03, November.

O’Neill, J. (2001), Building Better Global Economic BRICs. Global Economics Paper No. 66, Goldman Sachs, London.

Ornelas, E., J.L. Turner (2008), Trade Liberalization, Outsourcing, and the Hold-Up Problem. Journal of International Economics. 74(1): 225-241.

Paolino, P. (2001), Maximum likelihood estimation of models with beta-distributed dependent variables. Political Analysis 9(4): 325-346.

Ranjan, P., J.Y. Lee (2007), Contract Enforcement and International Trade. Economics and Politics 19(2): 191-218.

Rauch, J.E. (1999), Networks versus markets in international trade. Journal of International Economics 48(1): 7-35.

Roberts, M.J., J.R. Tybout (1997), The Decision to Export in Colombia: An Empirical Model of Entry with Sunk Costs. American Economic Review 87(4): 545-564.

Roberts, M.J., Y.X. Daniel, F. Xiaoyan, S. Zhang (2012), A Structural Model of Demand, Cost, and Export Market Selection for Chinese Footwear Producers. NBER Working Paper 17725.

Smithson, M., J. Verkuilen (2006), A better lemon squeezer? Maximum likelihood regression with beta-distributed dependent variables. Psychological Methods 11(1): 54-71.

Söderlund, B., P. Tingvall (2014), Dynamic Effects of Institutions on Firm-Level Exports. Review of World Economics 150: 277-308. DOI: 10.1007/s10290-013-0181-2.

Turrini, A., T. Ypersele (2010), Traders, Courts, and the Border Effect Puzzle. Regional Science and Urban Economics 40(2-3): 81-91.

Williamson, O.E. (1985), The Economic New Institutions of Capitalism. JNY: Free Press.

Williamson, O.E. (1996), The Mechanisms of Governance. Oxford: Oxford University Press.

Williamson, O.E. (2000), The New Institutional Economics: Taking Stock, Looking Ahead. Journal of Economic Literature 38(3): 595-613.

Wilson, D., K. Trivedi, S. Carlson, J. Ursúa (2011), The BRICs 10 Years On: Halfway Through the Great Transformation. Global Economics Paper No. 208, Goldman Sachs Global Economics, Commodities and Strategy Research, New York: Goldman Sachs.

Corresponding author: Patrik Gustavsson Tingvall, The Ratio Institute, Box 3203,Sveavägen 59, 10364 Stockholm, Sweden.

patrik.tingvall@ratio.se 
Bengt Söderlund, Stockholm School of Economics and The Ratio Institute, Box 3203, Sveavägen 59, 10364 Stockholm, Sweden.

bengt.soderlund@ratio.se

Ari Kokko, Copenhagen Business School, Department of International Economics and Management, Porcelaenshaven 24B, 2000 Fredriksberg, Danmark

ako.int@cbs.dk 